\title{
Archaeal intact polar lipids in polar waters: a comparison between the Amundsen and Scotia seas
}

\author{
Charlotte L. Spencer-Jones ${ }^{1}$, Erin L. McClymont ${ }^{1}$, Nicole J. Bale ${ }^{2}$, Ellen C. Hopmans ${ }^{2}$, Stefan Schouten ${ }^{2,3}$, \\ Juliane Müller $^{4}$, E. Povl Abrahamsen ${ }^{5}$, Claire Allen ${ }^{5}$, Torsten Bickert ${ }^{6}$, Claus-Dieter Hillenbrand ${ }^{5}$, Elaine Mawbey $^{5}$, \\ Victoria Peck $^{5}$, Aleksandra Svalova ${ }^{7}$, and James A. Smith ${ }^{5}$ \\ ${ }^{1}$ Department of Geography, Durham University, Lower Mountjoy, South Road, Durham, DH1 3LE, UK \\ ${ }^{2}$ NIOZ Royal Netherlands Institute for Sea Research, Department of Marine Microbiology and Biogeochemistry, \\ P.O. Box 59, 1790 AB Den Burg, Texel, the Netherlands \\ ${ }^{3}$ Department of Earth Sciences, Utrecht University, Utrecht, the Netherlands \\ ${ }^{4}$ Alfred Wegener Institute, Helmholtz Centre for Polar and Marine Research, 27568 Bremerhaven, Germany \\ ${ }^{5}$ British Antarctic Survey, High Cross, Madingley Road, Cambridge, CB3 0ET, UK \\ ${ }^{6}$ MARUM - Center for Marine Environmental Sciences, University of Bremen, Leobener Str. 8, 28359, Bremen, Germany \\ ${ }^{7}$ School of Natural and Environmental Sciences, Newcastle University, Newcastle-upon-Tyne, NE1 7RU, UK
}

Correspondence: Charlotte L. Spencer-Jones (charlotte.spencer-jones@open.ac.uk)

Received: 7 September 2020 - Discussion started: 5 November 2020

Revised: 3 March 2021 - Accepted: 23 March 2021 - Published: 11 June 2021

\begin{abstract}
The West Antarctic Ice Sheet (WAIS) is one of the largest potential sources of future sea-level rise, with glaciers draining the WAIS thinning at an accelerating rate over the past 40 years. Due to complexities in calibrating palaeoceanographic proxies for the Southern Ocean, it remains difficult to assess whether similar changes have occurred earlier during the Holocene or whether there is underlying centennial- to millennial-scale forcing in oceanic variability. Archaeal lipid-based proxies, specifically glycerol dialkyl glycerol tetraether (GDGT; e.g. TEX 86 and $\mathrm{TEX}_{86}^{L}$ ), are powerful tools for reconstructing ocean temperature, but these proxies have been shown previously to be difficult to apply to the Southern Ocean. A greater understanding of the parameters that control Southern Ocean GDGT distributions would improve the application of these biomarker proxies and thus help provide a longer-term perspective on ocean forcing of Antarctic ice sheet changes. In this study, we characterised intact polar lipid (IPL)-GDGTs, representing (recently) living archaeal populations in suspended particulate matter (SPM) from the Amundsen Sea and the Scotia Sea. SPM samples from the Amundsen Sea were collected from up to four water column depths representing the surface waters through to Circumpolar Deep Water (CDW), whereas the Scotia Sea samples were collected along a transect en-
\end{abstract}

compassing the sub-Antarctic front through to the southern boundary of the Antarctic Circumpolar Current. IPL-GDGTs with low cyclic diversity were detected throughout the water column with high relative abundances of hydroxylated IPLGDGTs identified in both the Amundsen and Scotia seas. Results from the Scotia Sea show shifts in IPL-GDGT signatures across well-defined fronts of the Southern Ocean. Indicating that the physicochemical parameters of these water masses determine changes in IPL-GDGT distributions. The Amundsen Sea results identified GDGTs with hexosephosphohexose head groups in the CDW, suggesting active GDGT synthesis at these depths. These results suggest that GDGTs synthesised at CDW depths may be a significant source of GDGTs exported to the sedimentary record and that temperature reconstructions based on $\mathrm{TEX}_{86}$ or $\mathrm{TEX}_{86}^{L}$ proxies may be significantly influenced by the warmer waters of the CDW. 


\section{Introduction}

Over the past ca. 50 years the West Antarctic Ice Sheet (WAIS) has lost ice mass at an accelerating rate, with some suggesting that the complete collapse of the WAIS may already be underway (Joughin et al., 2014; Mouginot et al., 2014; Rignot et al., 2019). The WAIS is grounded below sea level, and the edges of the ice sheet are floating ice shelves that are highly sensitive to changes in ocean properties. Widespread ice sheet/shelf thinning will likely have influence on biogeochemical cycling through ocean productivity (Raiswell et al., 2008; Menviel et al., 2010; Wadham et al., 2013), carbon reservoirs, and carbon sequestration (Yager et al., 2012; Wadham et al., 2019), in addition to sea ice and ocean circulation changes (Menviel et al., 2010).

One of the challenges in understanding and predicting the behaviour of WAIS is a lack of long-term ocean temperature records (i.e. prior to the satellite era $\sim 1992$ ). Such records are needed to better understand the links between WAIS stability, physical properties of the Southern Ocean, and biogeochemistry which might vary on centennial to millennial timescales (Smith et al., 2017; Hillenbrand et al., 2017). Organic geochemical proxies based on the ratios of archaeal membrane lipids can be used to reconstruct past ocean temperature and biogeochemistry. Glycerol dialkyl glycerol tetraether (GDGT) lipids are particularly promising, with the $\mathrm{TEX}_{86}, \mathrm{TEX}_{86}^{L}$, and OH-GDGT proxies having been widely used to reconstruct ocean temperatures in tropical, temperate, and northern polar regions (e.g. Jenkyns et al., 2004; Huguet et al., 2006, 2011; Sinninghe Damsté et al., 2010; Darfeuil et al., 2016). In contrast, only a handful of studies have successfully applied these proxies in the Southern Ocean (Kim et al., 2012; Shevenell et al., 2011; Etourneau et al., 2013, 2019). This reflects a combination of low concentrations of GDGTs with an incomplete understanding of archaeal populations and habitat/niche preference (Kim et al., 2010). A better understanding of the source of GDGTs in the Southern Ocean and factors that impact archaeal populations could improve application of $\mathrm{TEX}_{86}$-based proxies in this environment.

\section{Tracing archaea with intact polar lipids}

Archaea are a key component of picoplankton within the polar oceans (Delong et al., 1994; Murray et al., 1998; Church et al., 2003; Kirchman et al., 2007; Alonso-Saez et al., 2008) and have an important role in biogeochemical cycling and in marine food webs. GDGTs are important cell membrane components present in many marine archaea (Schouten et al., 2013a, and references therein), including the ammonia oxidising archaea (AOA) Thaumarchaeota (previously assigned to the phylum Crenarchaeota; Brochier-Armanet et al., 2008; Spang et al., 2010). Marine archaea produce isoprenoid GDGTs with a polar head group (intact polar lipids - IPLs). Upon cell death the polar head group is relatively rapidly cleaved off, resulting in the preservation of the core GDGT lipid (c-GDGTs). c-GDGTs are subsequently preserved in the sedimentary record and can be used to reconstruct Antarctic palaeoenvironmental change over long timescales (Kim et al., 2012; Shevenell et al., 2011; Etourneau et al., 2013, 2019). Thaumarchaeota are a major source of GDGTs to the environment with pure culture studies detecting GDGTs with 0-3 cyclopentane moieties, crenarchaeol (cren, which contains four cyclopentane moieties and a cyclohexane moiety), and the cren regioisomer (cren', Schouten et al., 2000; Sinninghe Damsté et al., 2018). Other archaeal phyla (e.g. marine Euryarchaeota group II) have been hypothesised as sources of GDGTs to the marine realm (Lincoln et al., 2014a, b); however, this source is unlikely to be significant in marine samples (Schouten et al., 2014; Zeng et al., 2019; Besseling et al., 2020). Furthermore, archaea exist throughout the marine water column, with several studies suggesting a GDGT contribution to sediments from deep water Thaumarchaeota (e.g. Ingalls et al., 2006; Shah et al., 2008; Kim et al., 2016).

IPL-GDGTs may be used as proxies for tracing (recently) living archaeal populations (e.g. Pitcher et al., 2011; Sinninghe Damsté et al., 2012; Elling et al., 2014, 2017). AOA enrichment cultures reveal three common GDGT head groups - monohexose $(\mathrm{MH})$, dihexose $(\mathrm{DH})$, and hexosephosphohexose (HPH) (Schouten et al., 2008; Pitcher et al., 2010, 2011) - with all three IPL head groups reported in environmental samples (Lipp et al., 2008; Lipp and Hinrichs, 2009; Schubotz et al., 2009; Schouten et al., 2012; Xie et al., 2014; Evans et al., 2017; Sollich et al., 2017; Besseling et al., 2018). HPHs are a common IPL in all AOA enrichment cultures to date, with $\mathrm{MH}$ and DH intermittently present (Pitcher et al., 2011; Elling et al., 2017; Bale et al., 2019). The interpretation of IPL-GDGTs as proxies for living archaeal biomass is complicated by their degradation to c-GDGTs with increasing evidence that some IPLs are preserved following cell death (Bauersachs et al., 2010; Huguet et al., 2010; Schouten et al., 2010; Xie et al., 2013; Lengger et al., 2014). Kinetic modelling has suggested greater preservation of glycolipids compared with phospholipids (Schouten et al., 2010), therefore suggesting that HPH-GDGTs may have potential as biomarkers for living, metabolically active thaumarchaeotal populations (Schouten et al., 2012; Elling et al., 2014, 2017). However, HPH-GDGT abundance is variable across the I.1a Thaumarchaeota clade, which could make the interpretation of this biomarker in environmental studies complex (Elling et al., 2017). DH-GDGTs and DH-OHGDGT on the other hand are thought to be produced exclusively by I.1a Thaumarchaeota with more uniform abundance across the clade (Pitcher et al., 2011; Sinninghe Damsté et al., 2012) and could therefore be potential tracers for living Thaumarchaeota (Elling et al., 2017).

In this study, we present the first characterisation of IPLGDGTs in suspended particulate matter (SPM) from two locations in the Southern Ocean, the Scotia Sea and the 
Amundsen Sea. The first aim of this study is to characterise the distributions of IPL-GDGTs within the Southern Ocean in order to expand our understanding of thaumarchaeotal distributions in polar regions and improve our interpretation of GDGT-based proxies. The second aim of this study is to understand the environmental controls on IPL-GDGT distributions in the Southern Ocean. In this study, we analyse the water column profiles of IPL-GDGTs with 18 samples from the Amundsen Sea and 30 samples from a transect in the Scotia and Weddell Sea.

\section{Methodology}

\subsection{Study area}

The Southern Ocean drives the global thermohaline circulation and is therefore a major regulator of Earth's oceans and climate (Carter et al., 2009). The eastward-flowing Antarctic Circumpolar Current (ACC) connects all the major ocean basins, resulting in a major role in the distribution of heat, salt, and gases (Carter et al., 2009). The surface waters of the Southern Ocean show clear shifts in water properties (salinity and temperature), which mark ocean fronts and in the present study include the sub-Antarctic front (SAF), the polar front (PF), the southern front of the ACC (SACCF), and the southern boundary of the ACC (SBACC) (Carter et al., 2009, and references therein). Antarctic surface waters (AASWs; $100 \mathrm{~m}$ thick), extending from the Antarctic continental shelf to the PF, are characterised by near-freezing temperatures and salinity values up to 34.3 practical salinity units (PSU), although these properties can vary on a regional basis (Carter et al., 2009, and references therein). The transition between AASW south of the PF and sub-Antarctic surface water (SASW) north of the SAF occurs in the Polar Frontal Zone. Due to complex mixing processes, the properties of surface water in the Polar Frontal Zone are often variable, but this water is generally warmer $\left(3-8^{\circ} \mathrm{C}\right)$ and less dense (salinity 34-34.4 PSU) than AASW (Carter et al., 2009, and references therein). Lastly, SASW is comparatively warmer (6$12^{\circ} \mathrm{C}$ ), with salinity $>34.3$ PSU (Carter et al., 2009, and references therein). Circumpolar Deep Water (CDW) together with CDW-derived, modified deep water masses, such as Warm Deep Water in the Weddell Gyre (e.g. Vernet et al., 2019), is a key Southern Ocean water mass and can be detected between $\sim 1400$ and $>3500$ m depth offshore from the Antarctic continent. CDW can rise to meet AASW or even outcrop along the Antarctic continental margin (Carter et al., 2009, and references therein). Mixing of CDW with different water masses gives rise to two types: upper CDW (UCDW) defined by an oxygen minimum, high nutrient concentrations, and a depth of 1400-2500 m; and lower CDW (LCDW) defined by a salinity maximum of 34.70-34.75 PSU (Carter et al., 2009, and references therein). In contrast to UCDW, LCDW extends south of the SBACC (Orsi et al.,
1995), is upwelled at the continental slope, and can protrude onto the shelf where it mixes with shelf waters cooled by interactions with the ice shelves and atmosphere (sometimes below the surface freezing point), renewing LCDW and forming Antarctic Bottom Water (AABW) (Carter et al., 2009, and references therein).

The Scotia Sea is located in the eastern Atlantic sector of the Southern Ocean $\left(20\right.$ to $\left.65^{\circ} \mathrm{W}\right)$ bounded by the South Atlantic Ocean to the north, by the Drake Passage to the west, and by the Weddell Sea to the south (Fig. 1). The Scotia Sea is influenced by the eastward flow of the ACC, via the Drake Passage, and by a northward component of the ACC, caused by topographic steering and northward outflow of recently ventilated waters from the Weddell Sea, whereby Weddell Sea Deep Water (WSDW) is incorporated into the ACC (Locarnini et al., 1993; Naveira Garabato et al., 2002a, b), thus creating a region of high mixing (Heywood et al., 2002) and intense water mass modification (Locarnini et al., 1993).

The Amundsen Sea extends from 100 to $130^{\circ} \mathrm{W}$ and is bounded by the sub-Antarctic Pacific to the north (Fig. 1). The Amundsen Sea water column south of the PF mainly consist of a thin upper layer of cold and fresh AASW overlying relatively warm CDW. The Amundsen Sea Embayment is located offshore from one of the major WAIS drainage basins, and observations show a clear trend in glacial retreat over recent decades (e.g. Mouginot et al., 2014; Paolo et al., 2015; Rignot et al., 2019). The deep ice shelves (extending up to $1000 \mathrm{~m}$ below sea level) surrounding the Amundsen Sea Embayment are exposed to unmodified CDW which can be up to $4{ }^{\circ} \mathrm{C}$ above the in situ freezing point (Jacobs et al., 1996, 2011; Rignot and Jacobs, 2002; Jenkins et al., 2010; Rignot et al., 2013; Webber et al., 2017) so that CDW may drive enhanced melt rates and ice sheet instability in this region (Shepherd et al., 2001; Zwally et al., 2005; Rignot et al., 2008; Pritchard et al., 2009; Wingham et al., 2009).

\subsection{Sample collection}

A Seabird Scientific SBE 911plus conductivitytemperature-depth (CTD) instrument with a 24-bottle rosette was used to vertically profile the water column and collect water for organic geochemical analysis. Water was collected on board the RRS James Clark Ross (expeditions JR272 and JR257) during March-April 2012 (austral autumn) from 15 stations along the former WOCE A23 section (Meredith et al., 2001) traversing the Scotia Sea between the northern Weddell Sea and South Georgia (Table 1 and Fig. 1; Allen et al., 2012; Venables et al., 2012), as well as on board the R/V Polarstern expedition PS104 during February-March 2017 (austral summer) from five stations in the Amundsen Sea Embayment (Table 2 and Fig. 1; Gohl, 2017). Water samples were collected in $10 \mathrm{~L}$ Niskin bottles. In the Scotia Sea, the depth of the sample collection was dependent on the expression of the mixed layer and seasonal thermocline as observed during each CTD deployment. At 


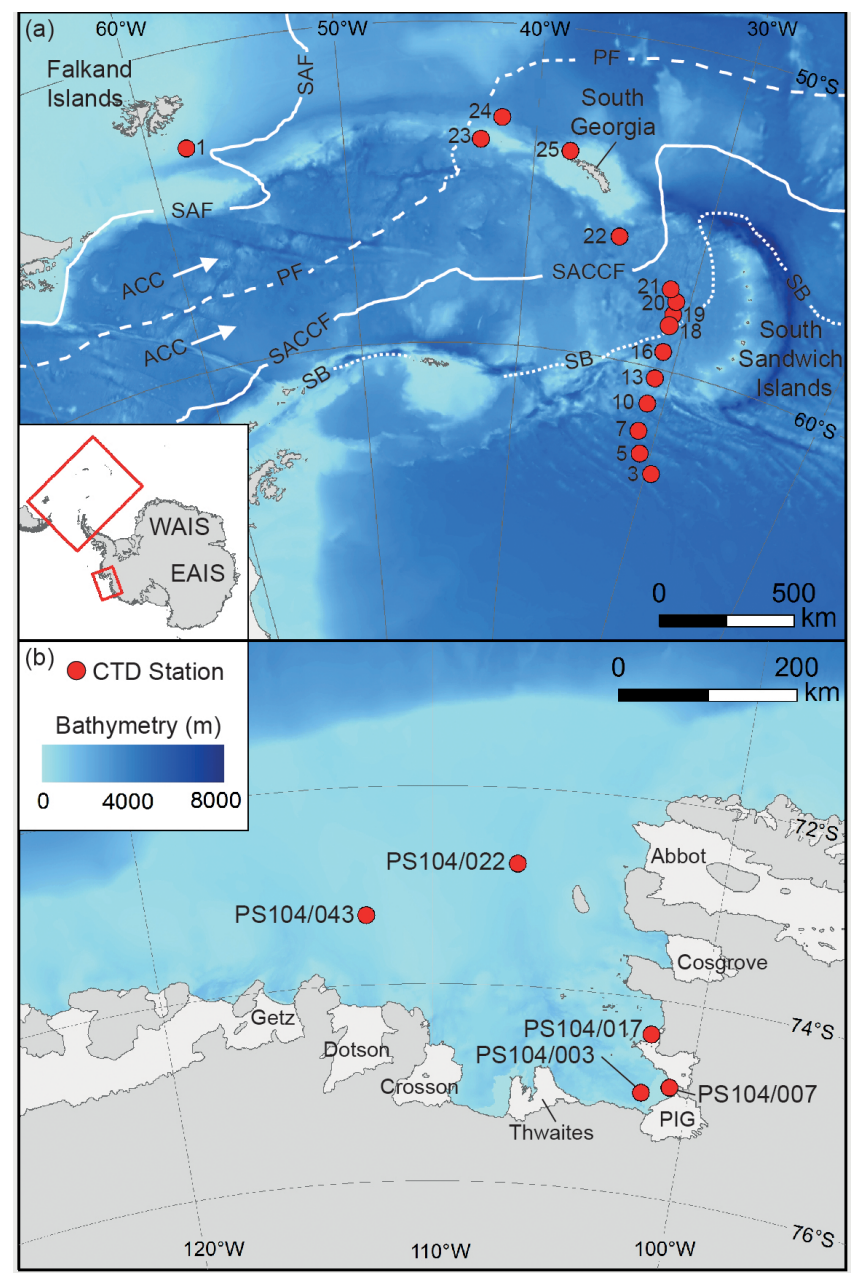

Figure 1. Map showing studied CTD sampling stations (red dots) in the Scotia Sea (a) and Amundsen Sea (b). The main oceanic fronts are also shown in panel (a): sub-Antarctic front (SAF), polar front (PF), southern ACC (SACCF), and the southern boundary of the ACC (SB) (Sokolov and Rintoul, 2009). The names of the ice shelves are shown in panel (b).

all stations, a "mixed layer" sample was collected between $10-40 \mathrm{~m}$ depth, and a "thermocline layer" sample was collected between approximately $60-110 \mathrm{~m}$ depth (Table 1). In the Amundsen Sea, the sampling strategy included samples from surface, thermocline waters, and CDW. Water samples (approximately 10-30L) were vacuum filtered through pre-combusted $\mathrm{GF} / \mathrm{F}$ filters (Whatman, $0.7 \mu \mathrm{m}$ pore size, $50 \mathrm{~mm}$ diameter). Glass fibre filters with a nominal pore size of $0.7 \mu \mathrm{m}$ are most commonly used for sampling of SPM in ocean and lake waters. However, as microbes can range in size from $0.2-0.7 \mu \mathrm{m}$, these filters may lead to an under-sampling of archaeal cells that are not associated with aggregates (Lee et al., 1995; Ingalls et al., 2012). Therefore, IPL-GDGT concentrations reported here represent the minimum likely concentrations.
The filters were subsequently stored in foil at $-20^{\circ} \mathrm{C}$ and then transported to Durham University (UK; Scotia Sea samples) and the Alfred Wegener Institute (Germany; Amundsen Sea samples). Samples were freeze-dried prior to lipid extraction.

\subsection{Sample extraction}

Total lipids of the Scotia Sea sample set were extracted at the Royal Netherlands Institute for Sea Research. Freeze-dried samples were extracted using a modified Bligh and Dyer methodology as detailed in Besseling et al. (2018). Briefly, sample filters were cut into small pieces using solventcleaned scissors. The total lipids were extracted using a monophasic mixture of $\mathrm{K}_{2} \mathrm{HPO}_{4}\left(8 \mathrm{~g} \mathrm{~L}^{-1}\right.$ adjusted to $\mathrm{pH} 7-$ 8), dichloromethane $\left(\mathrm{CH}_{2} \mathrm{Cl}_{2}\right)$, and methanol $\left(\mathrm{CH}_{3} \mathrm{OH}\right)$ at a ratio of $0.8: 1: 2$. Extractions were repeated three times and pooled. The pooled extract was subsequently phase separated by adjusting the ratio of $\mathrm{K}_{2} \mathrm{HPO}_{4}: \mathrm{CH}_{2} \mathrm{Cl}_{2}: \mathrm{CH}_{3} \mathrm{OH}$ to $0.9: 1: 1$. The $\mathrm{CH}_{2} \mathrm{Cl}_{2}$ layer of the resultant biphasic mixture was transferred to a round-bottom flask. This was repeated three times and the Bligh-Dyer extract dried under a stream of $\mathrm{N}_{2}$.

Total lipids of the Amundsen Sea sample set were extracted at the Alfred Wegener Institute (Germany). Freezedried samples were extracted ultrasonically using $\mathrm{CH}_{2} \mathrm{Cl}_{2}$ and $\mathrm{CH}_{3} \mathrm{OH}$ at a ratio of $2: 1$ for $15 \mathrm{~min}$. This was repeated three times, the extracts pooled and dried under a stream of $\mathrm{N}_{2}$. The resulting total lipid extract was fractionated over a silica column using hexane (for elution of the alkanes and highly branched isoprenoids) followed by $\mathrm{CH}_{2} \mathrm{Cl}_{2}$ : hexane and $\mathrm{CH}_{2} \mathrm{Cl}_{2}: \mathrm{CH}_{3} \mathrm{OH}$ both at a ratio of $1: 1$ for elution of the polar fraction. The polar fraction was dried under $\mathrm{N}_{2}$ and stored at $-20^{\circ} \mathrm{C}$ prior to IPL-GDGT analysis. The method used for the extraction of the Amundsen Sea samples is not the Bligh-Dyer protocol most commonly used for IPLGDGT extraction. Extraction technique has not been found to significantly affect c-GDGTs recovery (Schouten et al., 2013b; Weber et al., 2017) but has been found to have a greater influence on IPL-GDGT recovery due to differences in polar moieties (Weber et al., 2017). Weber et al. (2017) found extraction procedure to impact the absolute quantification of GDGTs along with the recovery of cren' (underquantified) and GDGT-3 (over-quantified). Sample purification using silica gel column chromatography has also been found to have an impact on IPL-GDGT recovery (Pitcher et al., 2009; Lengger et al., 2012) with HPH-GDGTs underquantified (Lengger et al., 2012). We acknowledge that there may be some differences in IPL-GDGT recovery between the Amundsen and Scotia Sea samples due to differences in extraction and work-up technique. However, we propose that comparison can still be made between the two seas as we do not report absolute quantities of IPL-GDGTs as the methods are semi-quantitative, we do not report the occurrence of $\mathrm{cren}^{\prime}$, and GDGT-3 was below the detection limit 
Table 1. Scotia Sea SPM samples studied and their physical properties including sample depth (m) and sample layer where "M" denotes mixed layer and "T" denotes thermocline layer, GDGT-0 / cren, and Ring Index.

\begin{tabular}{|c|c|c|c|c|c|c|c|c|c|}
\hline $\begin{array}{l}\text { Latitude } \\
\left({ }^{\circ} \mathrm{N}\right)\end{array}$ & $\begin{array}{r}\text { Longitude } \\
\left({ }^{\circ} \mathrm{E}\right)\end{array}$ & Station & $\begin{array}{r}\text { Sample } \\
\text { depth (m) }\end{array}$ & Layer & $\begin{array}{r}\text { Temperature } \\
\left({ }^{\circ} \mathrm{C}\right)\end{array}$ & $\begin{array}{r}\text { Salinity } \\
\text { (PSU) }\end{array}$ & $\begin{array}{l}\text { Fluorescence } \\
\qquad\left(\mathrm{mL} \mathrm{m}^{-3}\right)\end{array}$ & $\begin{array}{r}\text { GDGT- } 0 / \\
\text { cren }\end{array}$ & $\begin{array}{l}\text { Ring } \\
\text { Index }\end{array}$ \\
\hline-53.013 & -58.04 & CTD 1 & 15 & M & 7.31 & 33.99 & 0.41 & 2.6 & 0.9 \\
\hline-53.013 & -58.04 & CTD 1 & 100 & $\mathrm{~T}$ & 6.12 & 34.03 & 0.13 & 6.7 & 0.4 \\
\hline-53.586 & -42.835 & CTD 23 & 20 & M & 4.07 & 33.72 & 0.32 & & \\
\hline-53.586 & -42.835 & CTD 23 & 100 & $\mathrm{~T}$ & 2.23 & 33.81 & 0.08 & 1.8 & 0.7 \\
\hline-52.88 & -41.787 & CTD 24 & 15 & M & 3.55 & 33.72 & 1.09 & & \\
\hline-52.88 & -41.787 & CTD 24 & 80 & $\mathrm{~T}$ & 1.67 & 33.88 & 0.09 & 1.6 & 0.9 \\
\hline-53.743 & -38.155 & CTD 25 & 10 & M & 3.17 & 33.62 & 0.66 & & \\
\hline-53.743 & -38.155 & CTD 25 & 80 & $\mathrm{~T}$ & 1.95 & 33.91 & 0.05 & 2.4 & 0.8 \\
\hline-57.119 & -31.815 & CTD 22 & 30 & M & 1.34 & 33.82 & 0.24 & & \\
\hline-56.167 & -34.816 & CTD 22 & 110 & $\mathrm{~T}$ & 0.84 & 34.12 & 0.09 & 1.9 & 0.5 \\
\hline-57.459 & -31.327 & CTD 21 & 30 & M & 1.48 & 33.85 & 0.27 & & \\
\hline-57.459 & -31.327 & CTD 21 & 110 & $\mathrm{~T}$ & 1.34 & 34.3 & 0.03 & 5.3 & 0.2 \\
\hline-57.803 & -30.83 & CTD 20 & 30 & M & 1.60 & 33.92 & 0.28 & 2.2 & 1.0 \\
\hline-57.803 & -30.83 & CTD 20 & 110 & $\mathrm{~T}$ & 1.01 & 34.15 & 0.06 & 6.8 & 0.2 \\
\hline-58.213 & -30.822 & CTD 19 & 20 & M & 1.29 & 33.9 & 0.27 & & \\
\hline-58.213 & -30.822 & CTD 19 & 80 & $\mathrm{~T}$ & 1.16 & 34.19 & 0.09 & 8.0 & 0.3 \\
\hline-58.624 & -30.821 & CTD 18 & 20 & M & 0.65 & 33.69 & 0.17 & & \\
\hline-58.624 & -30.821 & CTD 18 & 90 & $\mathrm{~T}$ & -0.83 & 33.99 & 0.17 & 4.1 & 0.6 \\
\hline-59.436 & -30.861 & CTD 16 & 20 & M & -0.64 & 33.67 & 0.17 & & \\
\hline-59.436 & -30.861 & CTD 16 & 70 & $\mathrm{~T}$ & -1.32 & 34.12 & 0.08 & 16.8 & 1.0 \\
\hline-60.319 & -30.961 & CTD 13 & 30 & $\mathrm{M}$ & -0.89 & 33.74 & 0.11 & & \\
\hline-60.319 & -30.961 & CTD 13 & 65 & $\mathrm{~T}$ & -1.16 & 34.01 & 0.11 & 4.6 & 0.6 \\
\hline-61.171 & -31.045 & CTD 10 & 30 & M & -1.08 & 33.82 & 0.15 & & \\
\hline-61.171 & -31.045 & CTD 10 & 80 & $\mathrm{~T}$ & -1.08 & 34.23 & 0.11 & 177.6 & 0.02 \\
\hline-62.084 & -31.174 & CTD 7 & 40 & M & -1.11 & 33.87 & 0.4 & & \\
\hline-62.084 & -31.174 & CTD 7 & 75 & $\mathrm{~T}$ & -1.54 & 34.33 & 0.16 & 21.7 & 0.1 \\
\hline-62.784 & -30.706 & CTD 5 & 20 & M & -1.13 & 33.87 & 0.28 & & \\
\hline-62.784 & -30.706 & CTD 5 & 70 & $\mathrm{~T}$ & -1.49 & 34.34 & 0.14 & 4.3 & 0.7 \\
\hline-63.346 & -29.569 & CTD 3 & 20 & M & -1.18 & 33.8 & 0.22 & & \\
\hline-63.346 & -29.569 & CTD 3 & 60 & $\mathrm{~T}$ & -1.58 & 34.31 & 0.21 & 9.9 & 0.3 \\
\hline
\end{tabular}

of the instrument. An internal standard of 1-O-hexadecyl2-acetyl-sn-glycero-3-phosphocholine was added to both the Amundsen and Scotia Sea samples. The Bligh-Dyer extract (Scotia Sea) and polar fraction (Amundsen Sea) were filtered through true regenerated cellulose filters $(4 \mathrm{~mm}, 0.45 \mu \mathrm{m}$ pore size) using hexane, propan-2-ol, and water at a ratio of $79: 20: 1$. Samples were stored at $-20^{\circ} \mathrm{C}$ prior to analysis.

\subsection{Intact polar lipid characterisation}

IPL-GDGTs were analysed using a modification of the Sturt et al. (2004) methodology as detailed in Besseling et al. (2018) - to summarise, an Agilent 1290 Infinity I UHPLC, equipped with a thermostated auto-injector and column oven, coupled to a $Q$ Exactive Orbitrap MS with Ion Max source with a heated electrospray ionisation (HESI) probe (Thermo Fisher Scientific, Waltham, MA, USA). Separation was achieved using a YMC-Triart Diol-HILIC column $(250 \times 2.0 \mathrm{~mm}, 1.9 \mu \mathrm{m}$ particle size, $12 \mathrm{~nm}$ pore size; YMC Co., Ltd., Kyoto, Japan) maintained at $30^{\circ} \mathrm{C}$ with a flow rate of $0.2 \mathrm{~mL} \mathrm{~min}^{-1}$. Chromatographic separation of IPLGDGTs was achieved using the following $70 \mathrm{~min}$ program: $0 \%$ eluent B from $0-5$ min, linear gradient to $34 \%$ eluent B at $25 \mathrm{~min}$, isocratic $25-40 \mathrm{~min}$, linear gradient to $60 \% \mathrm{~B}$ at $55 \mathrm{~min}$, linear gradient to $70 \% \mathrm{~B}$ at $65 \mathrm{~min}$, followed by a re-equilibration time of $20 \mathrm{~min}$ between each analysis. Eluent $\mathrm{A}$ is hexane / propan-2-ol / formic acid / $14.8 \mathrm{M} \mathrm{NH}_{3}$ aq $(79: 20: 0.12: 0.04[v / v / v / v])$, and eluent $\mathrm{B}$ is propan-2$\mathrm{ol} /$ water / formic acid / $14.8 \mathrm{M} \mathrm{NH}_{3}$ aq $(88: 10: 0.12: 0.04$ $[v / v / v / v])$. HESI sheath gas, auxiliary gas, and sweep gas $\mathrm{N}_{2}$ pressures were 35,10 , and 10 (arbitrary units) respectively with the auxiliary gas at $50^{\circ} \mathrm{C}$. The spray voltage was $4.0 \mathrm{kV}$ (positive ion ESI), $S$-lens $70 \mathrm{~V}$, and capillary temperature $275^{\circ} \mathrm{C}$. Mass range monitored was between $\mathrm{m} / z 375$ and 2000 (resolving power of $70000 \mathrm{ppm}$ at $\mathrm{m} / z$ 200) followed by data-dependent fragmentation of the 10 most abundant masses in the mass spectrum (with the exclusion of isotope peaks) fragmented successively (stepped normalised collision energy $15,22.5$, and 30 ; isolation window $1.0 \mathrm{~m} / z$ ). 
Table 2. Amundsen Sea SPM samples studied and their physical properties, GDGT-0 / cren, and Ring Index.

\begin{tabular}{|c|c|c|c|c|c|c|c|c|}
\hline $\begin{array}{l}\text { Latitude } \\
\left({ }^{\circ} \mathrm{N}\right)\end{array}$ & $\begin{array}{r}\text { Longitude } \\
\left({ }^{\circ} \mathrm{E}\right)\end{array}$ & Station & $\begin{array}{r}\text { Sample depth } \\
\text { (m) }\end{array}$ & $\begin{array}{r}\text { Temperature } \\
\left({ }^{\circ} \mathrm{C}\right)\end{array}$ & $\begin{array}{r}\text { Salinity } \\
\text { (PSU) }\end{array}$ & $\begin{array}{r}\text { Fluorescence } \\
\qquad\left(\mathrm{mL} \mathrm{m}^{-3}\right)\end{array}$ & $\begin{array}{r}\text { GDGT-0/ } \\
\text { cren }\end{array}$ & $\begin{array}{l}\text { Ring } \\
\text { Index }\end{array}$ \\
\hline-74.958 & -101.829 & PS104/003-1 & 10 & -0.72 & 33.96 & 0.48 & 7.3 & 0.5 \\
\hline-74.958 & -101.829 & PS104/003-1 & 120 & -1.19 & 34.13 & 0.01 & 4.8 & 0.5 \\
\hline-74.958 & -101.829 & PS104/003-1 & 180 & -1.23 & 34.17 & 0.01 & 27.0 & 0.03 \\
\hline-74.958 & -101.829 & PS104/003-1 & 998 & 1.01 & 34.67 & -0.02 & 4.8 & 0.7 \\
\hline-74.866 & -100.76 & PS104/007-1 & 20 & -0.12 & 33.52 & 3.78 & 8.2 & 0.4 \\
\hline-74.866 & -100.76 & PS104/007-1 & 120 & -0.91 & 34.08 & 0.01 & 4.9 & 0.5 \\
\hline-74.866 & -100.76 & PS104/007-1 & 240 & -1.33 & 34.14 & -0.01 & 5.0 & 0.4 \\
\hline-74.866 & -100.76 & PS104/007-1 & 685 & 0.87 & 34.63 & -0.02 & 4.2 & 0.6 \\
\hline-74.359 & -101.747 & PS104/017-1 & 10 & -0.17 & 33.42 & 7.89 & & \\
\hline-74.359 & -101.747 & PS104/017-1 & 150 & -1.61 & 34.16 & 0.01 & 5.8 & 0.3 \\
\hline-74.359 & -101.747 & PS104/017-1 & 1375 & 1.06 & 34.71 & -0.02 & 2.8 & 0.9 \\
\hline-72.768 & -107.093 & PS104/022-1 & 10 & -0.59 & 33.13 & 1.09 & & \\
\hline-72.768 & -107.093 & PS104/022-1 & 30 & -0.47 & 33.27 & 1.71 & & \\
\hline-72.768 & -107.093 & PS104/022-1 & 120 & -1.54 & 34.1 & 0.07 & 3.8 & 0.6 \\
\hline-72.768 & -107.093 & PS104/022-1 & 697 & 0.98 & 34.71 & -0.02 & 4.2 & 0.6 \\
\hline-73.297 & -112.328 & PS104/043-2 & 10 & -1.34 & 32.82 & 1.51 & & \\
\hline-73.297 & -112.328 & PS104/043-2 & 120 & -1.62 & 34.18 & 0.01 & 3.3 & 0.5 \\
\hline-73.297 & -112.328 & PS104/043-2 & 454 & 0.15 & 34.51 & -0.02 & 5.4 & 0.5 \\
\hline
\end{tabular}

A dynamic exclusion window of $6 \mathrm{~s}$ was used as well as an inclusion list with a mass tolerance of 3 ppm to target specific compounds (absolute $m / z$ values of IPL-GDGTs can be found in Supplement A, and structures are found in Supplement B Fig. S1). The Q Exactive Orbitrap MS was calibrated within a mass accuracy range of $1 \mathrm{ppm}$ using the Thermo Scientific Pierce LTQ Velos ESI Positive Ion Calibration Solution (containing a mixture of caffeine, MRFA, Ultramark 1621, and $N$-butylamine in an acetonitrile-methanolacetic-acid solution). Peak areas for each individual IPL were determined by integrating the combined mass chromatograms (within $3 \mathrm{ppm}$ ) of the monoisotopic and first isotope peak of all the relevant adducts formed (protonated, ammoniated, and/or sodiated). IPL-GDGTs were examined in terms of their MS peak area response. Thus, the relative abundance of the peak area does not necessarily reflect the actual relative abundance of the different IPL-GDGTs; however, this method allows for the comparison between samples analysed in this study. The peak areas were determined from extracted ion chromatograms of the $[\mathrm{M}+\mathrm{H}]^{+},\left[\mathrm{M}+\mathrm{NH}_{4}\right]^{+}$, and $[\mathrm{M}+\mathrm{Na}]^{+}$for each individual IPL-GDGT species. CGDGT lipids were not analysed.

\subsection{Data analysis}

Standards for individual IPL-GDGTs are not available, and therefore concentrations reported here are semi-quantitative. IPL-GDGT peak areas were normalised to the internal standard and volume of water filtered and are reported as units $\mathrm{L}^{-1}$. The Ring Index (RI) was calculated based on Zhang et al. (2016).
Redundancy analysis (RDA) was performed on the Scotia Sea data set in RStudio (version 1.2.1335) using vegan (Oksanen et al., 2019) and faraway (Faraway, 2016) packages. RDA was performed using data normalised to the internal standard and total water volume extracted (scaled). Temperature, salinity, oxygen concentration, and chlorophyll $a$ fluorescence (hereafter referred to as fluorescence) were selected as explanatory variables, and IPL-GDGT relative abundances are the response variables. The statistical significance of RDA, axes, and explanatory variables was determined using an ANOVA-like test (Legendre et al., 2011).

\section{Results}

\subsection{Physicochemical properties of the water column}

CTD measurements were taken at all five stations in the Amundsen Sea: PS104/003, PS104/007, PS104/017, PS104/022, and PS104/043. Temperature-salinity $(T-S)$ plots are shown in Fig. 2 and Supplement B Fig. S2. At the time of sampling, water masses in the Amundsen Sea study area were characterised by a temperature range of -1.7 to $+1.1^{\circ} \mathrm{C}$, a salinity range of 32.8 to $34.7 \mathrm{PSU}$, and a dissolved oxygen concentration of between 183.9 and $386.2 \mu \mathrm{mol} \mathrm{kg}^{-1}$. Three different water masses are detected in the Amundsen Sea from the $T-S$ plot: AASW, CDW, and modified CDW (Fig. 2). Fluorescence peaked at the surface within the uppermost $20 \mathrm{~m}$, followed by a steep decline with depth (Supplement B Fig. S2). High fluorescence values were observed at PS104/017 with a value of $8 \mathrm{mg} \mathrm{m}^{-3}$ and PS104/007 with a value of $4 \mathrm{mg} \mathrm{m}^{-3}$, whereas low 
fluorescence values were observed at stations PS104/003, PS104/022, and PS104/043 (Supplement B Fig. S2).

The Scotia Sea study area encompasses the SAF, PF, SACCF, and the SBACC (Fig. 1a) and is characterised by a temperature range of -1.6 to $+7.3^{\circ} \mathrm{C}$ and a salinity range of 33.6-34.7 PSU (Fig. 2). The temperature range of the mixed layer samples was -1.2 to $+7.3^{\circ} \mathrm{C}$, and the temperature range of the thermocline samples was -1.6 to $+6.1^{\circ} \mathrm{C}$. A clear partition between the sample stations is observed in the $T-S$ plot (Fig. 2), with consistently higher water temperatures found at stations north of CTD 19 and on average lower ocean temperatures south of CTD 18 . This region broadly marks the location of the SBACC at $\sim 58.6^{\circ} \mathrm{S}$ (Fig. 1a).

\subsection{Amundsen Sea depth profiles}

Archaeal IPLs were identified in the water column at all Amundsen Sea stations (Table 3, Fig. 3). The relative abundance of the regular GDGT core (i.e. non-hydroxylated) varied with depth ranging from $20 \%-100 \%$ of total IPLGDGTs (excluding depths where no IPL-GDGTs were identified; Table 3). PS104/003 and PS104/007 were found to have IPL-GDGTs in the uppermost surface sample (10 and $20 \mathrm{~m}$ depths respectively). The surface sample at PS104/003 (10 m) was dominated by non-hydroxylated GDGTs $(94.3 \%$ of total IPLs) with a lower relative abundance of OH-GDGT core type (5.7\% of total IPLs). Further to this, HPH-GDGT0 was the most abundant IPL-GDGT at this station $(81.8 \%$ of total IPLs), with HPH-cren contributing a smaller fraction of the total IPL-GDGTs $(11.1 \%)$. Low relative abundance of MH-GDGT-0 (<1\%), MH-cren (<1\%), MH-OH-GDGT-0 $(<1 \%)$, DH-OH-GDGT-0 (5.1\%), and MH-diOH-GDGT-0 $(<1 \%)$ was also observed at PS104/003 $10 \mathrm{~m}$. This contrasts with the surface sample at PS104/007 $(20 \mathrm{~m})$ where no OHGDGT-IPLs were detected and where the IPL-GDGT suite is split between MH-GDGT-0 (89.1\%) and MH-cren (10.9\%). IPL-GDGTs were not identified within the surface sample at PS104/017 (10 m) and the two mid-shelf stations, PS104/022 (10 and $30 \mathrm{~m}$ ) and PS104/043 (10 m). DH-GDGT-0 and DHcren are minor components of the IPL-GDGT suite with maximum relative abundance observed in the deepest samples for all Amundsen Sea stations. The relative abundance of IPL-GDGTs with a MH head group peaks in the mid-depths between 120 and $240 \mathrm{~m}$ (with the exception of the surface $20 \mathrm{~m}$ at PS104/007). The ratio of GDGT-0 / cren is variable throughout the Amundsen Sea stations, ranging from 2.8-8.2 (excluding samples with no GDGTs). The sample taken from $180 \mathrm{~m}$ water depth at PS104/003 exceeded this range with a GDGT-0 / cren ratio of 27.0 (Table 2).

\subsection{Scotia Sea transect}

Archaeal IPLs were detected within all 15 Scotia Sea stations. A clear depth trend in IPL-GDGTs can be observed where IPL-GDGTs were detected in the thermocline samples but were often below detection within the mixed layer (Table 4 and Fig. 4b). Exceptions to this are CTD 1, 16, 20, and 21, where IPL-GDGTs were present in both the mixed and thermocline layers. Relative abundance (\%) of IPL-GDGT cores and the degree of cyclicity remains constant along the Scotia Sea transect with IPL-GDGT head groups showing greater variation along the transect (Table 4). An increase in the relative abundance of the HPH head group is observed within the thermocline samples between CTD $22\left(53.5^{\circ} \mathrm{S}\right)$ and $5\left(63.3^{\circ} \mathrm{S}\right)$; this is coupled with a decrease in the relative abundance (\%) of $\mathrm{MH}$ and DH IPL-GDGT head groups (Fig. 4b). Mixed layer CTD 20 and 21 are dominated by $\mathrm{MH}$, CTD 16 is dominated by HPH, and the CTD 1 mixed layer contains a mixture of all three IPL-GDGT head groups. The GDGT-0 / cren ratio generally ranges from 1.6-9.9, but CTD 7 (21.7), 10 (177.6), and 16 (16.8), located at the thermocline, exceed this range due to low cren concentrations (Table 1). In preparation for RDA on the thermocline samples, biomarkers that were identified in fewer than three samples were designated "rare species" and were excluded from the analysis (GDGT-DH-0, GDGT-DH-1, and OH-GDGT-HPH0 excluded). This is because outliers can violate the linearity of the relationship between the response and explanatory variables (Legendre and Legendre, 2012). Samples CTD 1 and 25 were also excluded from the analysis. CTD 1 is located offshore of the Falkland Islands and is the only sample from north of the SAF, thus representing the only data point for the subantarctic zone of the Southern Ocean that is unlikely to be representative for the polar environment. CTD 25 , located close to South Georgia, was excluded due to high biomarker abundances (Fig. 4a) which could be due to exceptionally high productivity in this area (e.g. Atkinson et al., 2001). Variance inflation factors (VIFs) for the response variables were between 3.5 (fluorescence) and 11.4 (oxygen concentration) (Supplement C Table S1). The VIF for oxygen concentration is slightly higher than is typically acceptable for RDA. This is due to correlation between oxygen concentration and fluorescence $(R=0.63)$; however, as the $R$ is below 0.7 , this is unlikely to violate the assumptions of the RDA (Legendre and Legendre, 2012) (Supplement C Table S2). RDA shows $64 \%$ constrained variation, with RDA 1 and 2 accounting for $63 \%$ of the cumulative variation (Supplement C Tables S3-S5). The RDA is statistically significant ( $p=<0.05, f=3.5$ ); furthermore, RDA 1 is found to be statistically significant ( $p=<0.05, f=11.48$ ); however, RDA 2 is not significant ( $p=0.42, f=2.35$ ) (Supplement C Tables S10-S12). Species scores show HPHGDGT-0 and HPH-cren to load positive on RDA 1, with MH-GDGT-0, MH-cren, MH-OH-GDGT-MH-0, DH-OHGDGT-0, and MH-MH-diOH-GDGT-0 loading highly negatively on RDA 1 (Fig. 5). Of the explanatory variables tested, temperature is statistically significant at the $<0.05$ level $(f=8.56)$ and with salinity $(p=0.07, f=2.61)$ and oxygen concentration ( $p=0.09, f=2.58$ ) approaching significance (Supplement C Table 12). The site scores show 


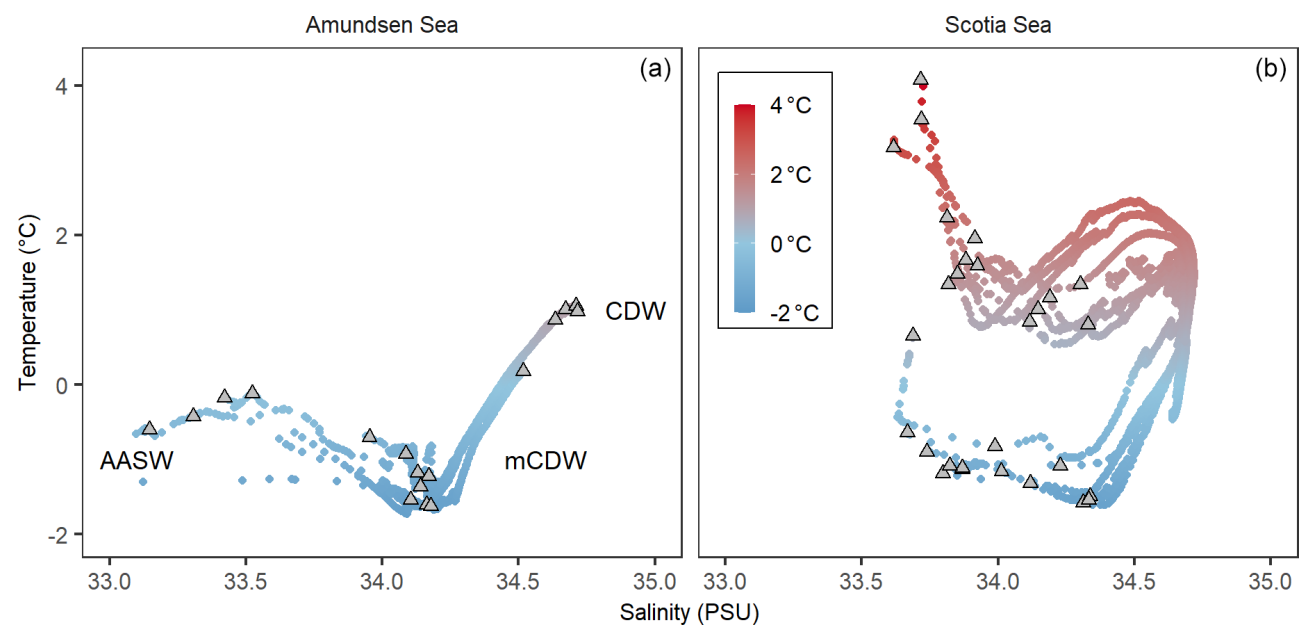

Figure 2. The temperature and salinity profiles $(T-S$ plot) for the Amundsen Sea (a) showing Antarctic Surface Water (AASW), Circumpolar Deep Water (CDW), and modified CDW (mCDW), and Scotia Sea (b). Coloured circles indicate the water column temperature of the water masses with the grey triangles indicating the water column sampling depths.

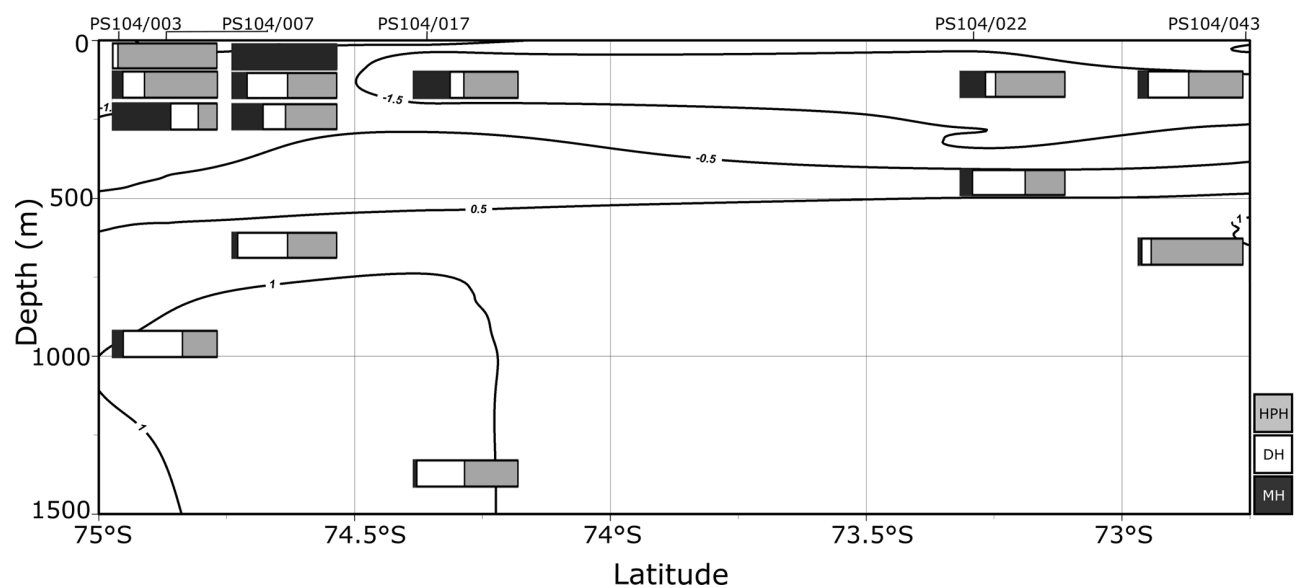

Figure 3. Relative abundance (\%) of IPL-GDGTs at approximate sample depths in the Amundsen Sea. Bars reflect IPL-GDGT head group, with black representing $\mathrm{MH}$ head groups, white representing DH, and grey representing HPH. Contour lines show approximate ocean temperature ranges using CTD data taken at each sample station with Ocean Data View DIVA gridding.

CTD 20, 21, 22, 23, and 24 to be negatively loaded on RDA 1 and CTD 3, 5, 7, 10, 13, 16, 18 and 19 to be positively loaded on RDA 1, suggesting that these stations are contrasted along this axis (Fig. 5).

\section{Discussion}

\subsection{Hydroxylated GDGTs in polar environments}

In this study, two hydroxylated GDGTs (OH-GDGT-0 and diOH-GDGT-0) were detected. Hydroxylated GDGTs have been reported as potential biomarkers for reconstructing ocean temperature change in cold waters (Fietz et al., 2013, 2016) and in this study contribute up to $49.8 \%$ (OH-GDGT) and $30.1 \%$ (diOH-GDGT) of total IPL-GDGTs. Hydroxy- lated IPL-GDGTs are not commonly reported in previous SPM studies (e.g. Kim et al., 2016; Kang et al., 2017; Hurley et al., 2018). However, these compounds have been reported as c-GDGTs in marine and lacustrine sediments, with hydroxylated GDGTs found to contribute approximately $8 \%$ in marine sediments from temperate and tropical sites (Liu et al., 2012; Lu et al., 2015). These compounds have been reported in much higher abundance in polar environments, including up to $20 \%$ in SPM and up to $16 \%$ in surface sediments from the Nordic Seas (Fietz et al., 2013) and up to $20 \%$ in surface sediments from the Southern Ocean (Huguet et al., 2013).

Exceptionally high hydroxylated GDGT relative abundances of greater than $20 \%$ could be due to differences in methodologies compared to the previous studies which measured core GDGTs by atmospheric pressure chemical ion- 
Table 3. Relative abundances (\%) and heat map of IPLs identified in Amundsen Sea. Relative abundances > 30\% indicated in red, low relative abundances $<10 \%$ indicated in yellow, and low relative abundances $<5 \%$ indicated in blue. "nd" means not detected.

\begin{tabular}{|c|c|c|c|c|c|c|c|c|c|c|c|c|c|}
\hline Station & $\begin{array}{l}\text { Depth } \\
\text { (cm) }\end{array}$ & $\begin{array}{l}\text { GDG } \\
\mathrm{MH}\end{array}$ & $\mathrm{DH}$ & $\mathrm{HPH}$ & $\begin{array}{l}\text { GDGT-1 } \\
\text { DH }\end{array}$ & $\begin{array}{l}\text { GDGT-2 } \\
\text { DH }\end{array}$ & $\mathrm{MH}$ & $\mathrm{DH}$ & & MH & DGT- & & $\begin{array}{l}\text { diOH- } \\
\text { GDGT-0 } \\
\text { MH }\end{array}$ \\
\hline PS104/003-1 & 10 & 1.2 & nd & 81.8 & nd & nd & 0.2 & nd & 11.1 & 0.4 & 5.1 & nd & 0.2 \\
\hline PS104/003-1 & 120 & 0.6 & 2.2 & 56.2 & 1.5 & nd & 0.3 & 0.1 & 11.7 & 4.9 & 16.5 & 0.5 & 5.5 \\
\hline PS104/003-1 & 180 & 1.4 & nd & 18.0 & nd & nd & 0.7 & nd & nd & 24.1 & 25.7 & nd & 30.1 \\
\hline PS104/003-1 & 998 & 3.4 & 11.3 & 28.1 & 14.7 & 8.2 & 1.7 & 3.0 & 4.3 & 5.2 & 18.8 & nd & 1.3 \\
\hline PS104/007-1 & 20 & 89.1 & nd & nd & nd & nd & 10.9 & nd & nd & nd & nd & nd & nd \\
\hline PS104/007-1 & 120 & 1.4 & 4.6 & 38.8 & 5.1 & 1.9 & 1.0 & 0.4 & 7.7 & 6.9 & 25.7 & nd & 6.5 \\
\hline PS104/007-1 & 240 & 2.3 & 5.7 & 40.0 & 3.3 & nd & 1.3 & nd & 8.3 & 11.8 & 11.9 & nd & 15.4 \\
\hline PS104/007-1 & 685 & 1.3 & 8.9 & 37.8 & 9.1 & 4.1 & 1.3 & 1.8 & 8.3 & 3.6 & 22.7 & nd & 1.1 \\
\hline PS104/017-1 & 10 & nd & nd & nd & nd & nd & nd & nd & nd & nd & nd & nd & nd \\
\hline PS104/017-1 & 150 & 1.7 & nd & 43.9 & nd & nd & 1.0 & nd & 6.8 & 14.1 & 13.0 & nd & 19.5 \\
\hline PS104/017-1 & 1375 & 0.9 & 6.5 & 38.2 & 11.1 & 7.3 & 1.1 & 3.0 & 11.9 & 2.4 & 17.3 & nd & 0.3 \\
\hline PS104/022-1 & 10 & nd & nd & nd & nd & nd & nd & nd & nd & nd & nd & nd & nd \\
\hline PS104/022-1 & 30 & nd & nd & nd & nd & nd & nd & nd & nd & nd & nd & nd & nd \\
\hline PS104/022-1 & 120 & 2.8 & nd & 51.6 & nd & nd & 1.7 & nd & 12.4 & 11.1 & 9.3 & 1.2 & 9.9 \\
\hline PS104/022-1 & 697 & 4.3 & 6.0 & 31.5 & 11.2 & 5.3 & 2.0 & 2.3 & 5.6 & 5.5 & 25.0 & nd & 1.2 \\
\hline PS104/043-2 & 10 & nd & nd & nd & nd & nd & nd & nd & nd & nd & nd & nd & nd \\
\hline PS104/043-2 & 120 & 1.6 & nd & 38.3 & nd & nd & 0.5 & nd & 11.5 & 4.6 & 37.9 & 0.9 & 4.7 \\
\hline PS104/043-2 & 454 & 0.7 & 0.2 & 72.3 & nd & nd & 0.2 & nd & 13.2 & 1.7 & 8.6 & 0.7 & 2.4 \\
\hline
\end{tabular}

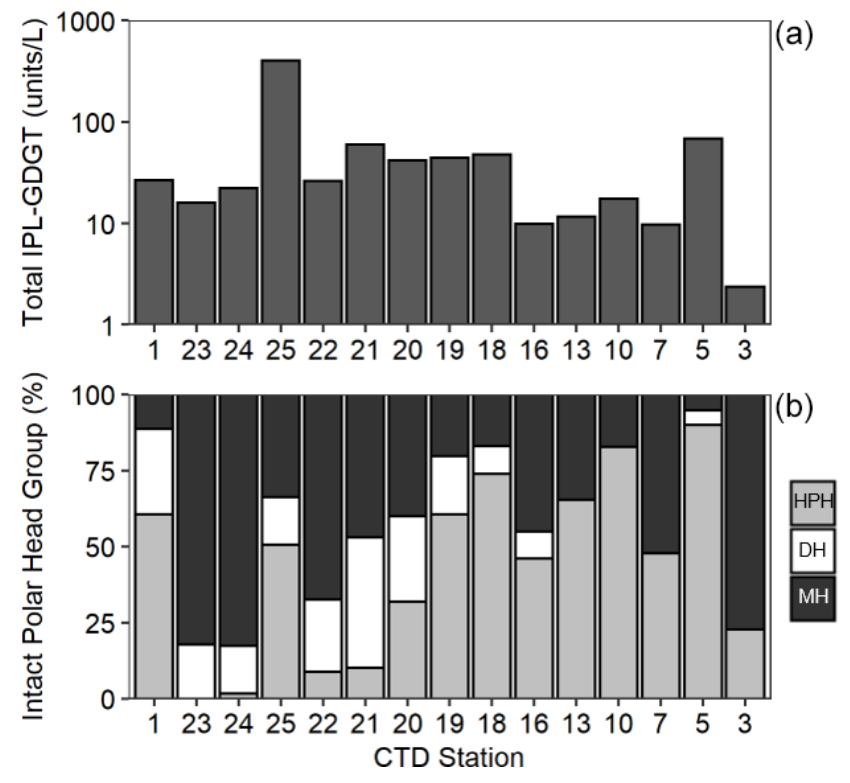

Figure 4. Total IPL-GDGT concentration $\left(\log _{10}\right.$, units $\mathrm{L}^{-1}$ ) (a) and relative abundance (\%) of IPL-GDGT head groups, monohexose (MH, black), dihexose ( $\mathrm{DH}$, white), and hexose-phosphohexose (HPH, grey) (b) in Scotia Sea thermocline samples (mixed layer samples excluded from plots).

isation (APCI; Liu et al., 2012; Fietz et al., 2013; Huguet et al., 2013; Lu et al., 2015), while this study examined IPL-GDGTs using electrospray ionisation (ESI). Using the same liquid chromatography-mass spectrometry (LC-MS) methodology, Sollai et al. (2019a) report average hydroxy- lated IPL-GDGT relative abundances of $22 \%( \pm 19 \%)$ with a range of $0 \%-51 \%$ in SPM from the euxinic Black Sea; however, similar analyses from the Arabian Sea (Besseling et al., 2018), the eastern tropical South Pacific (Sollai et al., 2019b), and the Mediterranean Sea did not detect hydroxylated IPL-GDGTs. Molecular dynamics simulations have shown that the addition of hydroxyl moieties in the tetraether structure increases the fluidity of the cell membrane and aids transmembrane transport in cold environments (Huguet et al., 2017). The exceptionally high amount of hydroxylated IPLGDGT for the Amundsen and Scotia seas may therefore be due to elevated synthesis of these biomarkers in cold environments.

\subsection{IPL-GDGT distributions as an indicator of archaeal populations}

In both the Amundsen and Scotia Sea samples, low diversity of cyclic GDGTs is observed (RI ranging from 0.021 for the Scotia Sea and 0.03-0.9 for the Amundsen Sea; Tables 1 and 2). This is particularly low compared with the $\mathrm{RI}$ of the global core top calibration, which includes a range of Southern Ocean samples, reporting an RI range of 1.253 (excluding the Red Sea samples; Kim et al., 2010; Ho et al., 2011, 2014; Zhang et al., 2016). Previous SPM studies spanning a range of marine habitats have reported the presence of hydroxylated GDGT-1, 2, and 3 as well as a wider range of non-hydroxylated GDGTs, such as GDGT-3 and 4 (Kim et al., 2016; Besseling et al., 2018; Hurley et al., 2018; Sollai et al., 2019a, b). As this study used the same analytical methodology as Besseling et al. (2018) and Sollai et 
Table 4. Relative abundances (\%) and heat map of IPLs identified in Scotia Sea. Relative abundances $>30 \%$ indicated in red, low relative abundances $<10 \%$ indicated in yellow, and low relative abundances $<5 \%$ indicated in blue. "nd" means not detected.

\begin{tabular}{|c|c|c|c|c|c|c|c|c|c|c|c|c|}
\hline \multirow[b]{2}{*}{ Station } & \multirow{2}{*}{$\begin{array}{l}\text { Depth } \\
(\mathrm{cm})\end{array}$} & \multicolumn{3}{|c|}{ GDGT-0 } & \multirow{2}{*}{$\begin{array}{l}\text { GDGT-1 } \\
\text { DH }\end{array}$} & \multicolumn{3}{|c|}{ Crenarchaeol } & \multicolumn{3}{|c|}{ OH-GDGT-0 } & \multirow{2}{*}{$\begin{array}{l}\text { diOH- } \\
\text { GDGT-0 } \\
\text { MH }\end{array}$} \\
\hline & & MH & $\mathrm{DH}$ & $\mathrm{HPH}$ & & $\mathrm{MH}$ & $\mathrm{DH}$ & $\mathrm{HPH}$ & $\mathrm{MH}$ & $\mathrm{DH}$ & $\mathrm{HPH}$ & \\
\hline 1 & 15 & 6.8 & nd & 49.6 & nd & 3.4 & nd & 18.6 & nd & 21.6 & \multirow{2}{*}{$\begin{array}{l}\text { nd } \\
\text { nd }\end{array}$} & nd \\
\hline 1 & 100 & 4.6 & nd & 54.9 & nd & 3.3 & nd & 5.6 & 2.6 & 28.2 & & 0.8 \\
\hline 23 & 20 & nd & \multirow{2}{*}{$\begin{array}{l}\text { nd } \\
\text { nd }\end{array}$} & nd & \multirow{2}{*}{$\begin{array}{l}\text { nd } \\
\text { nd }\end{array}$} & nd & \multirow{2}{*}{$\begin{array}{l}\text { nd } \\
\text { nd }\end{array}$} & \multirow{2}{*}{$\begin{array}{l}\text { nd } \\
\text { nd }\end{array}$} & nd & nd & \multirow{2}{*}{$\begin{array}{l}\text { nd } \\
\text { nd }\end{array}$} & nd \\
\hline 23 & 100 & 31.0 & & nd & & 16.8 & & & 19.6 & 17.7 & & 14.9 \\
\hline 24 & 15 & nd & \multirow{2}{*}{$\begin{array}{l}\text { nd } \\
\text { nd }\end{array}$} & nd & \multirow{2}{*}{$\begin{array}{l}\text { nd } \\
\text { nd }\end{array}$} & nd & \multirow{2}{*}{$\begin{array}{l}\text { nd } \\
\text { nd }\end{array}$} & \multirow{2}{*}{$\begin{array}{l}\text { nd } \\
\text { nd }\end{array}$} & nd & nd & \multirow{2}{*}{$\begin{array}{l}\text { nd } \\
\text { nd }\end{array}$} & nd \\
\hline 24 & 80 & 36.2 & & 1.6 & & 23.3 & & & 16.5 & 15.7 & & 6.7 \\
\hline 25 & 10 & nd & nd & nd & \multirow{2}{*}{$\begin{array}{l}\text { nd } \\
\text { nd }\end{array}$} & nd & \multirow{2}{*}{$\begin{array}{l}\text { nd } \\
\text { nd }\end{array}$} & nd & nd & nd & nd & nd \\
\hline 25 & 80 & 10.1 & 1.0 & 35.3 & & 6.1 & & 13.4 & 8.7 & 14.8 & 1.8 & 8.8 \\
\hline 22 & 30 & nd & \multirow{2}{*}{$\begin{array}{l}\text { nd } \\
\text { nd }\end{array}$} & nd & \multirow{2}{*}{$\begin{array}{l}\text { nd } \\
\text { nd }\end{array}$} & nd & \multirow{2}{*}{$\begin{array}{l}\text { nd } \\
\text { nd }\end{array}$} & \multirow{2}{*}{$\begin{array}{l}\text { nd } \\
\text { nd }\end{array}$} & nd & nd & \multirow{2}{*}{$\begin{array}{l}\text { nd } \\
\text { nd }\end{array}$} & nd \\
\hline 22 & 110 & 13.5 & & 8.8 & & 11.9 & & & 21.7 & 23.7 & & 20.4 \\
\hline 21 & 30 & 52.6 & nd & nd & nd & nd & \multirow{2}{*}{$\begin{array}{l}\text { nd } \\
\text { nd }\end{array}$} & nd & 47.4 & nd & \multirow{2}{*}{$\begin{array}{l}\text { nd } \\
\text { nd }\end{array}$} & nd \\
\hline 21 & 110 & 9.3 & 4.0 & 10.2 & 3.5 & 4.5 & & nd & 11.8 & 35.3 & & 21.4 \\
\hline 20 & 30 & 53.0 & nd & nd & nd & 24.5 & nd & nd & 22.5 & nd & nd & nd \\
\hline 20 & 110 & 9.0 & nd & 31.8 & nd & 6.0 & nd & nd & 12.4 & 28.2 & nd & 12.6 \\
\hline 19 & 20 & nd & nd & nd & nd & nd & nd & nd & nd & nd & nd & nd \\
\hline 19 & 80 & 3.1 & nd & 55.7 & nd & 2.6 & nd & 4.8 & 6.4 & 19.2 & nd & 8.2 \\
\hline 18 & 20 & nd & nd & nd & nd & nd & nd & nd & nd & nd & nd & nd \\
\hline 18 & 90 & 4.2 & nd & 57.8 & nd & 1.9 & nd & 13.4 & 4.7 & 9.2 & 2.6 & 6.2 \\
\hline 16 & 20 & nd & nd & 100.0 & nd & nd & nd & nd & nd & nd & nd & nd \\
\hline 16 & 70 & 7.8 & nd & 45.9 & nd & 3.2 & nd & nd & 20.6 & 8.9 & nd & 13.6 \\
\hline 13 & 30 & nd & nd & nd & nd & nd & nd & nd & nd & nd & nd & nd \\
\hline 13 & 65 & 15.3 & nd & 54.2 & nd & 4.1 & nd & 11.1 & 10.5 & nd & nd & 4.8 \\
\hline 10 & 30 & nd & nd & nd & nd & nd & nd & nd & nd & nd & nd & nd \\
\hline 10 & 80 & 4.2 & nd & 82.6 & nd & 0.5 & nd & nd & 7.0 & nd & nd & 5.7 \\
\hline 7 & 40 & nd & nd & nd & nd & nd & nd & nd & nd & nd & nd & nd \\
\hline 7 & 75 & 7.2 & nd & 47.7 & nd & 2.5 & nd & nd & 29.8 & nd & nd & 12.7 \\
\hline 5 & 20 & nd & nd & nd & nd & nd & nd & nd & nd & nd & nd & nd \\
\hline 5 & 70 & 0.7 & nd & 71.1 & nd & 0.4 & nd & 16.3 & 2.3 & 4.8 & 2.5 & 1.9 \\
\hline 3 & 20 & nd & nd & nd & nd & nd & nd & nd & nd & nd & nd & nd \\
\hline 3 & 60 & 45.2 & nd & 22.7 & nd & 6.9 & nd & nd & 25.2 & nd & nd & nd \\
\hline
\end{tabular}

al. (2019a, b), these differences cannot be attributed to analytical methodologies. Low cyclic diversity of GDGTs in the Amundsen and Scotia seas could be due to differences in the synthesis of these lipids by the source Thaumarchaeota. The relationship between ocean temperature and the cyclicity of GDGTs has been firmly established, with increasing ocean temperatures correlated with increasing relative abundance of GDGTs with two or more cyclopentane moieties (Schouten et al., 2002, 2007; Kim et al., 2008, 2010). However, Kim et al. (2010) note some differences between subtropical and subpolar oceans, with cren playing a more important role in temperature reconstructions in the subtropics than in polar oceans, suggesting that there may be differences in membrane adaptation strategies of Thaumarchaeota. Principal component analysis of IPL-GDGT distributions of a moderately thermophilic Thaumarchaeota along with previously published data identifies two distinct clusters with a clear partition between the orders of Nitrosopumilales and
Nitrososphaerales (Bale et al., 2019). IPL-GDGTs analysed in this study cluster within the Nitrosopumilales group due to the high relative abundances of GDGT- 0 and low relative abundances of all other GDGTs. Due to the polar locations of the Amundsen and Scotia Sea samples, Nitrosopumilales are likely to be the key AOA in these environments. Previous microbial analysis of the spatial variation in prokaryotes of the Amundsen Sea polynya indicated that the most abundant Thaumarchaeota marine group I (MGI) sequence belonged to the cluster affiliated with "Candidatus Nitrosopumilus maritimus" (Kim et al., 2014). In similar studies within the wider Southern Ocean region phylogenetic analysis reveals high abundances of sequences clustering with $\mathrm{Ni}$ trosopumilus. Hernandez et al. (2015) analysed surface water samples from Potter Cove (King George Island, western Antarctica Peninsula), which revealed that the majority of sequences fell into the clade containing "Candidatus Nitrosopumilus maritimus" and other environmental sequences 


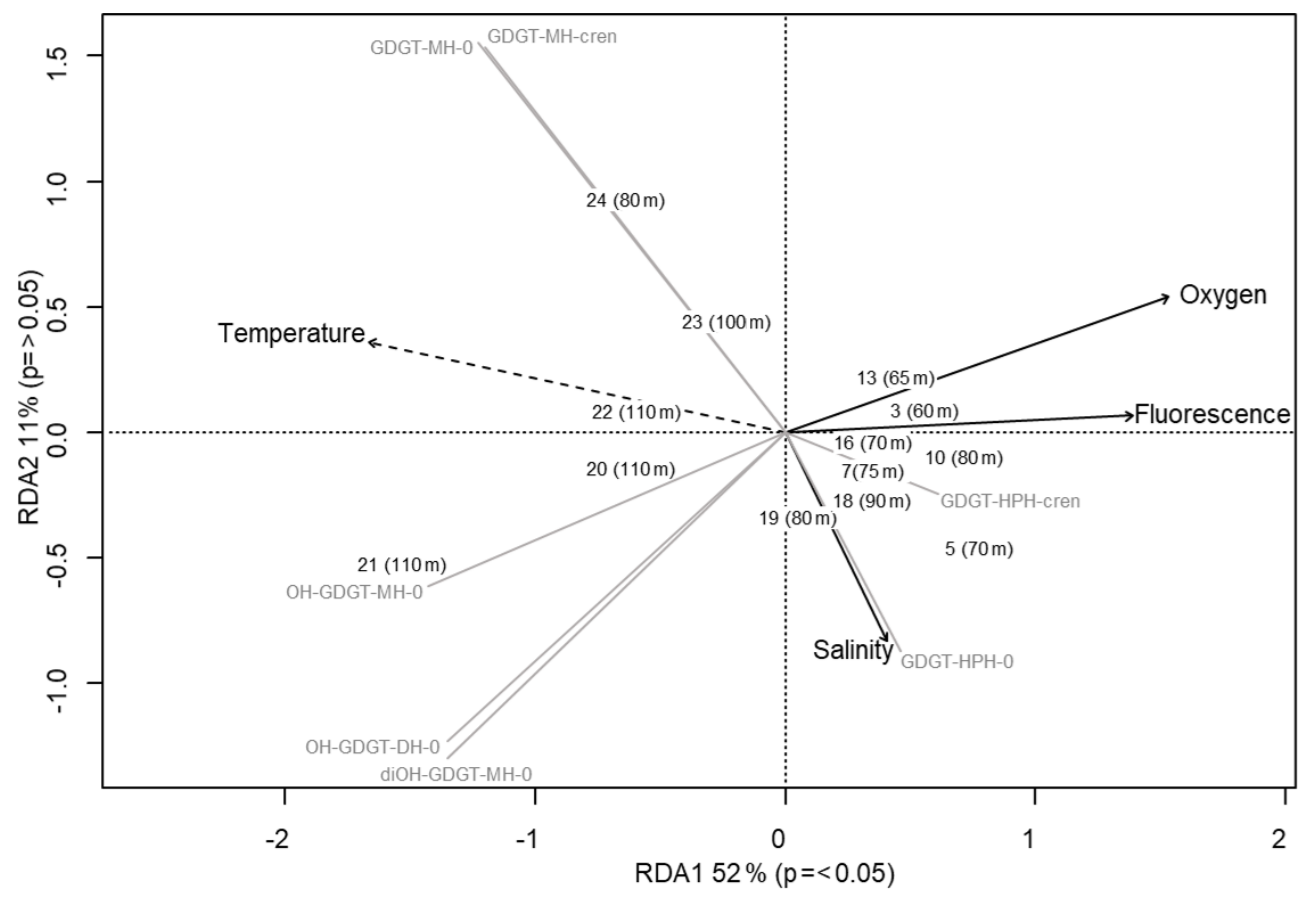

Figure 5. Redundancy analysis triplot for Scotia Sea sample set showing samples with depths, biomarker response variables (grey lines), and explanatory variables (black with dashed lines indicating statistical significance).

containing Thaumarchaeota. Signori et al. (2018) studied microbial spatial and temporal variability at 10 stations off the Antarctic Peninsula, revealing spring to be characterised by SAR11 and microbial communities remaining from winter, including Thaumarchaeota (Nitrosopumilus), Euryarchaeota, and SAR324, with a shift in microbial populations during the summer and autumn.

Three polar head groups were detected in this study, i.e. $\mathrm{MH}, \mathrm{DH}$, and HPH. All three head groups have previously been identified in culture (Schouten et al., 2008; Pitcher et al., 2011; Sinninghe Damsté et al., 2012; Elling et al., 2017) and environmental studies (e.g. Zhu et al., 2016; Besseling et al., 2018) and have widely been associated with Thaumarchaeota. It has been postulated that specific IPL-GDGTs may be associated with particular thaumarchaeotal groups or habitats (Sinninghe Damsté et al., 2012; Elling et al., 2017; Bale et al., 2019). Previously the HPH head group has been associated with the Nitrosopumilales order (group I.1a) and the DH head group with the Nitrososphaerales order (group I.1b) (Sinninghe Damsté et al., 2012). More recent studies have shown that environmental niche or habitat may be the main driver of GDGT head group composition rather than phylogeny (Elling et al., 2017; Bale et al., 2019). Relevant to this study, Elling et al. (2017) analysed the lipidome of 10 thaumarchaeotal cultures and identified DHGDGTs and DH-OH-GDGTs as key membrane components of the marine mesophiles compared with the terrestrial thermophilic and soil mesophilic Thaumarchaeota. In the present study, high abundances of HPH were detected, contributing up to $92.9 \%$ and up to $100 \%$ of total IPL-GDGTs in the Amundsen Sea and Scotia Sea respectively. The dominance of HPH in the lipid profiles of the Amundsen and Scotia seas aligns with previous culture analysis (Schouten et al., 2008; Pitcher et al., 2011; Sinninghe Damsté et al., 2012; Elling et al., 2017).

\subsection{Distribution of IPL-GDGTs in surface waters of Southern Ocean}

In this study, we observed a number of consistent trends in the water column IPL-GDGT distributions between the different Amundsen Sea and Scotia Sea sampling stations. In the surface samples, collected within the euphotic zone of the Amundsen Sea at PS104/017 (10 m), PS104/022 (10 and $30 \mathrm{~m}), \mathrm{PS} 104 / 043$ (10 m), and the Scotia Sea (15-40 m depth at CTD stations $3,5,7,10,13,18,19,22,23,24$, and 25), no IPL-GDGTs were identified. Previous studies from the Southern Ocean have shown water column archaeal distributions to be highly variable on both a temporal and spatial scale. Broadly, archaea (as measured by cell counts or rRNA) are often absent or found in relatively low abundance in the surface waters during the austral spring algal bloom and during austral summer (Massana et al., 1998; Church et al., 2003; Kalanetra et al., 2009; Besseling et al., 2020). The absence of archaea in the surface waters of the Southern Ocean contrasts with the high abundance of bacteria and is part of a larger seasonal cycle in archaeal population dynamics (Church et al., 2003). Temporal distributions of archaea 
are then shown to become more evenly distributed by depth, with an increase in the population within the surface waters throughout austral autumn-winter (Church et al., 2003). The Amundsen Sea samples were collected during austral summer. Two previous studies in the Antarctic Peninsula have shown an increase in group I archaeal populations in surface waters during austral summer and winter (Massana et al., 1998; Murray et al., 1998). However, Kalanetra et al. (2009) did not observe any archaea in surface waters west of the Antarctic Peninsula during austral summer. The mechanism for this temporal heterogeneity is likely mediated by a combination of physical and biological factors, including water mass properties and concentrations of dissolved and particulate organic carbon (Murray et al., 1998). Furthermore, the absence of AOA in the surface waters during austral spring, when primary productivity is highest, could be due to competition with bacteria and algae that bloom during the same time period and/or a subsequent nutrient limitation (Massana et al., 1998; Church et al., 2003; Kalanetra et al., 2009). As the current study was only performed at one time point during austral summer, a larger sampling campaign would be required to fully characterise microbial and IPL-GDGT seasonality in the Amundsen Sea.

In contrast with the other stations, the surface water samples from PS104/003 and PS104/007 (10 and 20 m respectively) and CTD 1, 16, 20, and 21 were found to contain IPLs. The samples from PS104/007 (10 m), CTD 20, and 21 only contained the MH head group. It should be noted that while the MH head group is known to be synthesised by archaea (e.g. Sinninghe Damsté et al., 2012), this IPL is recalcitrant and can be formed as a degradation product of other IPLGDGTs (e.g. Lengger et al., 2013, 2014). In contrast, HPH is more labile and less readily preserved in sediments following cell death and is hence considered to be a biomarker for recently active archaea and, in particular, Thaumarchaeota (Pitcher et al., 2010; Sinninghe Damsté et al., 2012). HPHcren can vary between phylogenetic subgroups (Elling et al., 2017), and while the DH head group is not as labile as HPH due to its glycosidic structure (Lengger et al., 2013), DHGDGTs have been identified with consistent relative abundances across the Nitrosopumilales order (group I.1a), suggesting DH-cren as an additional biomarker for AOA activity (Elling et al., 2017). Hence, the dominance of the MH head group at these stations may indicate an inactive/relic archaeal population at this depth. Higher IPL-GDGT diversity was detected at PS104/003 and CTD 1 and 16, including HPH and DH head groups indicating a recently active archaeal population (Sinninghe Damsté et al., 2012; Elling et al., 2017). PS104/003 is located in an area of active upwelling of nutrient-rich waters largely composed of CDW (Pine Island Bay polynya) (Mankoff et al., 2012). Together with the Amundsen polynya located north of Dotson and westernmost Getz ice shelves (Fig. 1), it is one of the most productive regions (per unit area) of the Southern Ocean (Arrigo and van Dijken, 2003). Productivity is further aided by the influx of iron released from the rapidly melting Thwaites and Pine Island glaciers (Alderkamp et al., 2012; Gerringa et al., 2012; Thuroczy et al., 2012; St-Laurent et al., 2017). Results from another cruise in the region identified that productivity is limited not only by nutrient and iron availability but also by light; productivity is $30 \%-50 \%$ lower in the Pine Island polynya compared to the Amundsen polynya, with this difference attributed to the significant difference in solar irradiance levels between the two polynyas throughout the summer season (Park et al., 2017). Similarly, CTD 1 is located close to the Falkland Islands in the subantarctic zone north of the SAF and is potentially subject to additional terrestrial inputs and coastal dynamics. Kalanetra et al. (2009) suggests that a combination of both light and nutrient differences between Arctic and Antarctic Ocean settings could cause the differences in archaeal populations in the surface ocean, where low light and nutrient levels in the surface allow archaeal populations to flourish, with further studies suggesting photoinhibition of Thaumarchaeota (Church et al., 2003; Mincer et al., 2007; Hu et al., 2011; Merbt et al., 2012; Luo et al., 2014).

\subsection{Influence of Circumpolar Deep Water on IPL distributions: Amundsen Sea}

IPL-GDGT diversity increased downwards in the water column through the thermocline and the CDW layer in the Amundsen Sea (Table 3). DH-cren and HPH-cren may be widely applied as biomarkers for recently active Thaumarchaeota populations having been identified as key cell membrane lipids (Pitcher et al., 2010; Sinninghe Damsté et al., 2012; Elling et al., 2017). HPH-cren was identified consistently throughout the thermocline and CDW layer at all Amundsen Sea stations (Table 3). Our results, therefore, suggest recently active AOA at the thermocline and within the CDW. Tolar et al. (2016) shows ammonia oxidation (AO) to occur throughout the water column, with similar rates of $\mathrm{AO}$ in CDW during both winter and summer seasons and increased $\mathrm{AO}$ in surface waters during the late winter in sites west of the Antarctic Peninsula. These patterns in AO are consistent with molecular microbiology studies from the Amundsen Sea and Antarctic Peninsula region that identified Thaumarchaeota throughout the water column, but with a seasonal trend where these archaea are often absent in the surface waters during spring and summer and present in the CDW throughout the year (Massana et al., 1998; AlonsoSaez et al., 2011). HPH-cren, however, may not be the most suitable proxy for tracking the complete AOA population as the relative abundance of this IPL can vary significantly between phylogenetic subgroups (Elling et al., 2017). DHGDGTs have been identified with consistent relative abundances across the Nitrosopumilales order (group I.1a), suggesting DH-cren as an additional biomarker for AOA activity (Elling et al., 2017). In this study we detect DH-cren consistently in the CDW layer and with low relative abundance in 
the thermocline of PS104/003 and PS104/007 and absence in the thermocline waters at PS104/017 and PS104/022. Thaumarchaeota are thought to partition between shallow water $(0-130 \mathrm{~m})$ and deep water $(500-4000 \mathrm{~m})$ marine clades (Francis et al., 2005; Hallam et al., 2006). Therefore, the depth trend of HPH-cren throughout the thermocline and CDW and DH-cren restricted to CDW depths could reflect differences in Thaumarchaeota populations in the Amundsen Sea. While the data presented here provide only a snapshot of the Amundsen Sea IPL-GDGT distributions, this small contrast in HPH and DH-cren distributions may represent a significant partition between Thaumarchaeota populations and warrants further analysis. Thaumarchaeota are not homogeneously distributed throughout the water column. Molecular microbiology has identified Thaumarchaeota to be virtually absent from Antarctic Summer Surface Waters (0-45 m depth) and present in Winter Water (45-105 m depth) and Circumpolar Deep Water (105-3500 m depth) (e.g. Kalanetra et al., 2009). Our observation of active IPL-GDGT synthesis within the CDW has implications for the use of c-GDGTbased biomarker proxies in the Amundsen Sea and potentially more broadly within the Southern Ocean. Indeed, temperature reconstructions based on GDGTs are suggested to represent the 45-200 $\mathrm{m}$ range (Kim et al., 2012), acknowledging the absence of Thaumarchaeota from the surface waters during the summer months in Antarctica. The influence of $\mathrm{CDW}$ on reconstructed $\mathrm{TEX}_{86}$ palaeotemperatures has been hypothesised in Adélie Land (East Antarctica), with Kim et al. (2012) suggesting warmer reconstructed temperatures were likely due to the upwelling of CDW onto the piston core site. In our study we specifically observe IPLGDGTs of recently living archaea in the CDW (over $500 \mathrm{~m}$ water depth). Furthermore, we observe a shift in head group composition at CDW depths in the Amundsen Sea, representing a shift in the IPL-GDGT-producing community. We hypothesise that the contribution of GDGTs synthesised at CDW depths where physical parameters (e.g. temperature) can be strikingly different to the 45-200 m water depth may have a significant impact on reconstructed $\mathrm{TEX}_{86}$ temperatures, not only the Amundsen Sea but potentially more broadly within the Southern Ocean.

\subsection{Influences on the GDGT-IPL distribution along the Scotia Sea transect}

IPL-GDGTs were found to be present within the thermocline $(60-110 \mathrm{~m})$ and contain a high proportion of $\mathrm{MH}$ head group IPL-GDGTs, suggesting a high proportion of relic IPL-GDGTs in the Scotia Sea that could relate to the seasonality of archaeal populations. Further to this, DH-cren was found to be absent from the thermocline with HPH-cren intermittently present. This pattern in DH-cren and HPHcren in the Scotia Sea is consistent with our results from the Amundsen Sea, where DH-cren was mostly absent from the 120-240 m depth intervals but present in the CDW depth in- tervals (i.e. below $400 \mathrm{~m}$ ), while HPH-cren was present at both the thermocline and CDW depths.

The Scotia Sea samples were collected along clear temperature $\left(-1.6\right.$ to $\left.+7.3^{\circ} \mathrm{C}\right)$, salinity (33.6-34.3 PSU), oxygen $\left(218.3-332.7 \mu \mathrm{mol} \mathrm{kg}{ }^{-1}\right)$, and fluorescence $(0.03-$ $1.1 \mathrm{~mL} \mathrm{~m}^{-3}$ ) gradients associated with ocean fronts, which are known to impact bacterioplankton population diversity (Wilkins et al., 2013; Baltar et al., 2016; Raes et al., 2018). Figure 5 shows that higher-latitude samples with cooler ocean temperatures cluster positively on RDA axis 1 and have higher relative abundances of HPH-GDGT-0 and HPHcren (samples 3, 5, 7, 10, 13, 16, 18, 19), whilst samples from warmer ocean waters and lower latitudes cluster negatively on RDA axis 1 and have higher relative abundances of MH and DH IPL-GDGTs (samples 20-24). The contrast in IPL head group distributions between CTD stations 319 and 20-24 suggests that RDA 1 represents the transition across the SBACC. Temperature was found to be a statistically significant explanatory variable in the RDA, which is consistent with previous research that has identified clear links between core GDGT relative abundances and environmental variables such as temperature (Schouten et al., 2007; Kim et al., 2008, 2010). Specifically, we observe a shift in the GDGT head group between the warmer and cooler waters of the ACC fronts. Temperature, along with other physicochemical properties (e.g. nutrient and oxygen concentrations), varies across the ACC (e.g. Rubin, 2003; Freeman et al., 2019). These shifts in physicochemical properties across permanent oceanic boundaries influence and control bacterial and archaeal species richness, creating ecological boundaries or niches (e.g. Raes et al., 2018). Variability in IPLGDGT head group composition observed across the Scotia Sea transect could reflect the transition across an environmental niche (e.g. Elling et al., 2017; Bale et al., 2019). As this study is limited by the number of chemical properties analysed, it would be speculative to infer the relative importance of specific nutrient concentrations across the Scotia Sea transect. Alternatively, the shift in IPL-GDGT head group could also be influenced by the presence of the Weddell Gyre, which is located south of $55-60^{\circ} \mathrm{S}$ and between $60^{\circ} \mathrm{W}$ and $30^{\circ} \mathrm{E}$ (Vernet et al., 2019). The Weddell Gyre is a region of enhanced productivity, with austral summer chlorophyll $a$ concentrations ranging from $1.5-10 \mathrm{mg} \mathrm{m}^{-3}$ (Bathmann et al., 1997; Cape et al., 2014) due to high concentrations of nutrients upwelled and circulated through the gyre (Vernet et al., 2019, and references therein).

\section{Conclusions}

A range of archaeal IPLs was detected in both the Amundsen Sea and the Scotia Sea. High relative abundances of $\mathrm{OH}-$ GDGT core type were observed, which could reflect the polar environmental setting of these samples. Low cyclicity was detected in both the Amundsen and Scotia seas for both the 
GDGT and OH-GDGT core type with acyclic OH-GDGT0 and GDGT- $0,1,2$, and cren reported. Low cyclicity of GDGTs may potentially be a more widespread feature of the Southern Ocean GDGT signature.

IPL-GDGT relative abundance along the Scotia Sea transect shows a distinct pattern across the oceanographic front transition. Samples south of the SBACC and from cooler ocean waters had higher relative abundances of HPH-GDGT0 and HPH-cren compared with samples north of the SBACC, while those from warmer ocean waters had higher relative abundances of MH and DH IPL-GDGTs. Indeed, RDA reveals that temperature is a significant explanatory variable; however, productivity and nutrient availability may also play a role in IPL-GDGT distributions. Additionally, this shift in IPL-GDGT distributions could represent a shift in the dominant archaeal IPL synthesisers and/or a physiological survival strategy.

In the Amundsen Sea IPL-GDGTs are detected throughout the water column. IPL-GDGTs of recently living archaea were specifically observed in the CDW (over $500 \mathrm{~m}$ water depth) along with a shift in head group composition at CDW depths, representing a shift in the IPL-GDGTproducing community. We hypothesise that the contribution of GDGTs synthesised at CDW depths where physical parameters, such as temperature, can be strikingly different to the upper water column (e.g. 0-200 m water depth) may have a significant impact on reconstructed $\mathrm{TEX}_{86}^{L}$ temperatures in not only the Amundsen Sea but potentially more broadly within the Southern Ocean.

Data availability. CTD data from JR257/JR272A are available from the British Oceanographic Data Centre at https://www.bodc. ac.uk/data/documents/cruise/11431/ (last access: 22 March 2021) (Allen et al., 2021).

Supplement. The supplement related to this article is available online at: https://doi.org/10.5194/bg-18-3485-2021-supplement.

Author contributions. CLSJ, ELM, JAS, CDH, and EM designed the experiments. CLSJ, ELM, NJB, ECH, and JM undertook the laboratory preparation and analysis. EPA, CA, TB, and VP generated the oceanographic data. CLSJ and AS undertook statistical analysis. CLSJ, ELM, JAS, NJB, ECH, and SS wrote the manuscript with contributions from all authors.

Competing interests. The authors declare that they have no conflict of interest.

Acknowledgements. This project was funded through a UK Natural Environment Research Council (NERC) Standard Grant, awarded to James A. Smith, Erin L. McClymont, Kate Hendry, and Claus-Dieter Hillenbrand (NE/M013081/1, NE/M013243/1, NE/M013782/1); a British Antarctic Survey Collaborative Gearing Scheme award (Erin L. McClymont); a Helmholtz research grant (VH-NG-1101; Juliane Müller); and the Durham University Department of Geography Research Development Fund (Charlotte L. Spencer-Jones). Nicole J. Bale is funded by the European Research Council (ERC) under the European Union's Horizon 2020 research and innovation programme (grant agreement no. 694569). Collection of CTD casts on the A23 transect was supported by NERC National Capability funding to BAS. We thank Martin D. West, Amanda J. Hayton, and Denise Dorhout for technical support. We are grateful to the captains, crews, support staff, and scientists participating in cruises JR257, JR272, and PS104, and we acknowledge funding for cruise PS104 by AWI, MARUM, BAS, and NERC UK-IODP. Lastly, we thank two anonymous reviewers for their constructive comments that improved the manuscript.

Financial support. This research has been supported by the Natural Environment Research Council (NERC) (grant nos. NE/M013081/1, NE/M013243/1, and NE/M013782/1), a Helmholtz research grant (grant no. VH-NG-1101), and the European Research Council, H2020 (MICROLIPIDS, grant no. 694569).

Review statement. This paper was edited by Carolin Löscher and reviewed by two anonymous referees.

\section{References}

Alderkamp, A.-C., Mills, M. M., van Dijken, G. L., Laan, P., Thuroczy, C.-E., Gerringa, L. J. A., de Baar, H. J. W., Payne, C. D., Visser, R. J. W., Buma, A. G. J., and Arrigo, K. R.: Iron from melting glaciers fuels phytoplankton blooms in the Amundsen Sea (Southern Ocean): Phytoplankton characteristics and productivity, Deep-Sea Res. Pt. II, 71-76, 32-48, https://doi.org/10.1016/j.dsr2.2012.03.005, 2012.

Allen, C. S., Peck, V. L., Graham, A. G. C., Blagbrough, H., Robinson, M. W., and McClymont, E.: RRS James Clark Ross Marine Science Cruises JR257 and JR254e, March-April 2012, British Antarctic Survey, Cambridge, UK, https://www.bodc.ac.uk/ resources/inventories/cruise_inventory/reports/jr257_254e.pdf, 2012.

Allen, C. S., Venables, H. J., and Yelland, M. J.: RRS James Clark Ross (74JC) cruise JR20120327 (JR254E, JR257, JR272A), National Oceanography Center, British Oceanographic Data Center BODC, available at: https://www.bodc.ac.uk/data/documents/ cruise/11431/, last access: 22 March 2021.

Alonso-Saez, L., Sanchez, O., Gasol, J. M., Balague, V., and Pedros-Alio, C.: Winter-to-summer changes in the composition and single-cell activity of near-surface Arctic prokaryotes, Environ. Microbiol., 10, 2444-2454, https://doi.org/10.1111/j.14622920.2008.01674.x, 2008.

Alonso-Saez, L., Andersson, A., Heinrich, F., and Bertilsson, S.: High archaeal diversity in Antarctic circumpolar deep waters, Env. Microbiol. Rep., 3, 689-697, https://doi.org/10.1111/j.1758-2229.2011.00282.x, 2011. 
Arrigo, K. and van Dijken, G.: Phytoplankton dynamics within 37 Antarctic coastal polynya systems, J. Geophys. Res.-Oceans, 108, 3271, https://doi.org/10.1029/2002JC001739, 2003.

Atkinson, A., Whitehouse, M. J., Priddle, J., Cripps, G. C., Ward, P., and Brandon, M. A.: South Georgia, Antarctic: a productive, cold water, pelagic ecosystem, Mar. Ecol. Prog. Ser., 216, 279308, https://doi.org/10.3354/meps216279, 2001.

Bale, N. J., Palatinszky, M., Rijpstra, W. I. C., Herbold, C. W., Wagner, M., and Sinninghe Damsté, J. S.: Membrane lipid composition of the moderately thermophilic ammonia-oxidising archaeon "Candidatus Nitrosotenuis uzonensis" at different growth temperatures, Appl. Environ. Microb., 85, e01332-19, https://doi.org/10.1128/AEM.01332-19, 2019.

Baltar, F., Currie, K., Stuck, E., Roosa, S., and Morales, S. E.: Oceanic fronts: transition zones for bacterioplankton community composition, Env. Microbiol. Rep., 8, 132-138, https://doi.org/10.1111/1758-2229.12362, 2016.

Bathmann, U. V., Scharek, R., Klaas, C., Dubischar, C. D., and Smetacek, V.: Spring development of phytoplankton biomass and composition in major water masses of the Atlantic sector of the Southern Ocean, Deep-Sea Res. Pt. II, 44, 51-67, https://doi.org/10.1016/S0967-0645(96)00063-X, 1997.

Bauersachs, T., Speelman, E. N., Hopmans, E. C., Reichart, G. J., Schouten, S., and Sinninghe Damsté, J. S.: Fossilized glycolipids reveal past oceanic $\mathrm{N}_{2}$ fixation by heterocystous cyanobacteria, P. Natl. Acad. Sci. USA, 107, 19190-19194, https://doi.org/10.1073/pnas.1007526107, 2010.

Besseling, M. A., Hopmans, E. C., Boschman, R. C., Sinninghe Damsté, J. S., and Villanueva, L.: Benthic archaea as potential sources of tetraether membrane lipids in sediments across an oxygen minimum zone, Biogeosciences, 15, 4047-4064, https://doi.org/10.5194/bg-15-4047-2018, 2018.

Besseling, M. A., Hopmans, E. C., Bale, N. J., Schouten, S., Sinninghe Damsté, J. S., and Villanueva, L.: The absence of intact polar lipid-derived GDGTs in marine waters dominated by Marine Group II: Implications for lipid biosynthesis in Archaea, Sci. Rep.-UK, 10, 294, https://doi.org/10.1038/s41598-019-57035-0, 2020.

Brochier-Armanet, C., Boussau, B., Gribaldo, S., and Forterre, P.: Mesophilic crenarchaeota: proposal for a third archaeal phylum, the Thaumarchaeota, Nat. Rev. Microbiol., 6, 245-252, https://doi.org/10.1038/nrmicro1852, 2008.

Cape, M. R., Vernet, M., Kahru, M., and Spreen, G.: Polynya dynamics drive primary production in the Larsen $\mathrm{A}$ and $\mathrm{B}$ embayments following ice shelf collapse, J. Geophys. Res.-Oceans, 119, 572-594, https://doi.org/10.1002/2013JC009441, 2014.

Carter, L., McCave, I. N., and Williams, M. J. M.: Circulation and water masses of the Southern Ocean: A Review, in: Developments in Earth and Environmental Sciences - Antarctic Climate Evolution, edited by: Florindo, F. and Siegert, M., Elsevier, Amsterdam, the Netherlands, 85-114, https://doi.org/10.1016/S15719197(08)00004-9, 2009.

Church, M. J., DeLong, E. F., Ducklow, H. W., Karner, M. B., Preston, C. M., and Karl, D. M.: Abundance and distribution of planktonic Archaea and Bacteria in the waters west of the Antarctic Peninsula, Limnol. Oceanogr., 48, 1893-1902, https://doi.org/10.4319/1o.2003.48.5.1893, 2003.

Darfeuil, S., Menot, G., Giraud, X., Rostek, F., Tachikaea, K., Garcia, M., and Bard, E.: Sea surface temperature reconstruc- tions over the last $70 \mathrm{kyr}$ off Portugal: Biomarker data and regional modelling, Paleoceanogr. Paleoclimatol., 31, 40-65, https://doi.org/10.1002/2015PA002831, 2016.

Delong, E. F., Wu, K. Y., Prezelin, B. B., and Jovine, R. V. M.: High abundance of archaea in Antarctic marine picoplankton, Nature, 371, 695-697, https://doi.org/10.1038/371695a0, 1994.

Elling, F. J., Konneke, M., Lipp, J. S., Becker, K. W., Gagen, E. J., and Hinrichs, K. U.: Effects of growth phase on the membrane lipid composition of the thaumarchaeon Nitrosopumilus maritimus and their implications for archaeal lipid distributions in the marine environment, Geochim. Cosmochim. Ac., 141, 579597, https://doi.org/10.1016/j.gca.2014.07.005, 2014.

Elling, F. J., Konneke, M., Nicol, G. W., Stieglmeier, M., Bayer, B., Spieck, E., de la Torre, J. R., Becker, K. W., Thomm, M., Prosser, J. I., Herndl, G. J., Schleper, C., and Hinrichs, K. U.: Chemotaxonomic characterisation of the Thaumarchaeal lipidome, Environ. Microbiol., 19, 2681-2700, https://doi.org/10.1111/14622920.13759, 2017.

Etourneau, J., Collins, L. G., Willmott, V., Kim, J.-H., Barbara, L., Leventer, A., Schouten, S., Sinninghe Damsté, J. S., Bianchini, A., Klein, V., Crosta, X., and Massé, G.: Holocene climate variations in the western Antarctic Peninsula: evidence for sea ice extent predominantly controlled by changes in insolation and ENSO variability, Clim. Past, 9, 1431-1446, https://doi.org/10.5194/cp-9-1431-2013, 2013.

Etourneau, J., Sgubin, G., Crosta, X., Swingedouw, D., Willmott, V., Barbara, L., Houssais, M.-N., Schouten, S., Sinninghe Damsté, J. S., Goosse, H., Escutia, C., Crespin, J., Massé, G., and Kim, J.-H.: Ocean temperature impact on ice shelf extent in the eastern Antarctic Peninsula, Nat. Commun., 10, 304, https://doi.org/10.1038/s41467-018-08195-6, 2019.

Evans, T. W., Wormer, L., Lever, M. A., Lipp, J. S., Lagostina, L., Lin, Y. S., Jorgensen, B. B., and Hinrichs, K. U.: Size and composition of subseafloor microbial community in the Benguela upwelling area examined from intact membrane lipid and DNA analysis, Org. Geochem., 111, 86-100, https://doi.org/10.1016/j.orggeochem.2017.06.008, 2017.

Faraway, J.: faraway: Functions and Datasets for Books by Julian Faraway, R-Package version 1.0.7, available at: https://CRAN.R-project.org/package=faraway (last access: 22 March 2021), 2016.

Fietz, S., Huguet, C., Rueda, G., Hambach, B., and Rosell-Melé, A.: Hydroxylated isoprenoidal GDGTs in the Nordic Seas, Mar. Chem., 152, 1-10, https://doi.org/10.1016/j.marchem.2013.02.007, 2013.

Fietz, S., Ho, S. L., Huguet, C., Rosell-Mele, A., and MartinezGarcia, A.: Appraising GDGT-based seawater temperature indices in the Southern Ocean, Org. Geochem., 102, 93-105, https://doi.org/10.1016/j.orggeochem.2016.10.003, 2016.

Francis, C. A., Roberts, K. J., Beman, J. M., Santoro, A. E., and Oakley, B. B.: Ubiquity and diversity of ammoniaoxidizing archaea in water columns and sediments of the ocean, P. Natl. Acad. Sci. USA, 102, 14683-14688, https://doi.org/10.1073/pnas.0506625102, 2005.

Freeman, N. M., Munro, D. R., Sprintall, J., Mazloff, M. R., Purkey, S., Rosso, I., DeRanek, C. A., and Sweeney, C.: The observed seasonal cycle of macronutrients in Drake Passage: Relationship to fronts and utility as a model metric, J. Geophys. Res.-Oceans, 124, 4763-4783, https://doi.org/10.1029/2019JC015052, 2019. 
Gerringa, L. J. A., Alderkamp, A.-C., Laan, P., Thuroczy, C.E., De Baar, H. J. W., Mills, M. M., van Dijken, G. L., van Haren, H., and Arrigo, K. R.: Iron from melting glaciers fuels the phytoplankton blooms in Amundsen Sea (Southern Ocean): Iron biogeochemistry, Deep-Sea Res. Pt. II, 71-76, 1631, https://doi.org/10.1016/j.dsr2.2012.03.007, 2012.

Gohl, K.: The Expedition PS104 of the Research Vessel POLARSTERN to the Amundsen Sea in 2017, Reports on Polar and Marine Research, Helmholtz-Zentrum für Polar- und Meeresforschung, Alfred-Wegener-Institut, Bremerhaven, Germany, 100 pp., https://doi.org/10.2312/BzPM_0712_2017, 2017.

Hallam, S. J., Mincer, T. J., Schleper, C., Preston, C. M., Roberts, K., Richardson, P. M., and DeLong, E. F.: Pathways of carbon assimilation and ammonia oxidation suggested by environmental genomic analyses of marine Crenarchaeota, Plos Biol., 4, 520536, https://doi.org/10.1371/journal.pbio.0040095, 2006.

Hernandez, E. A., Piquet, A. M. T., Lopez, J. L., Buma, A. G. J., and Mac Cormack, W. P.: Marine archaeal community structure from Potter Cove, Antarctica: high temporal and spatial dominance of the phylum Thaumarchaeota, Polar Biol., 38, 117-130, https://doi.org/10.1007/s00300-014-1569-8, 2015.

Heywood, K. J., Naveira Garabato, A. C., and Stevens, D. P.: High mixing rates in the abyssal Southern Ocean, Nature, 415, 10111014, https://doi.org/10.1038/4151011a, 2002.

Hillenbrand, C.-D., Smith, J. A., Hodell, D. A., Greaves, M., Poole, C. R., Kender, S., Williams, M., Andersen, T. J., Jernas, P. E., Elderfield, H., Klages, J. P., Roberts, S. J., Gohl, K., Larter, R. D., and Kuhn, G.: West Antarctic Ice Sheet retreat driven by Holocene warm water incursions, Nature, 547, 43-48, https://doi.org/10.1038/nature22995, 2017.

Ho, S. L., Yamamoto, M., Mollenhauer, G., and Minagawa, M.: Core top TEX $_{86}$ values in the South and equatorial Pacific, Org. Geochem., 42, 94-99, https://doi.org/10.1016/j.orggeochem.2010.10.012, 2011.

Ho, S. L., Mollenhauer, G., Feitz, S., Martinez-Garcia, A., Lamy, F., Rueda, G., Schipper, K., Méheust, M., Rosell-Melé, A., Stein, R., and Tiedemann, R.: Appraisal of $\mathrm{TEX}_{86}$ and $\mathrm{TEX}_{86}^{L}$ thermometries in subpolar and polar regions, Geochim. Cosmochim. Ac., 131, 213-226, https://doi.org/10.1016/j.gca.2014.01.001, 2014.

$\mathrm{Hu}$, A. Y., Jiao, N. Z., Zhang, R., and Yang, Z.: Niche partitioning of marine group I Crenarchaeota in the euphotic and upper mesopelagic zones of the East China Sea, Appl. Environ. Microb., 77, 7469-7478, https://doi.org/10.1128/Aem.00294-11, 2011

Huguet, C., Kim, J.-H., Sinninghe Damsté, J. S., and Schouten, S.: Reconstruction of sea surface temperature variations in the Arabian Sea over the last $23 \mathrm{kyr}$ using organic proxies TEX $_{86}$ and $\mathrm{U}_{37}^{K^{\prime}}$ ), Paleoceanogr. Paleoclimatol., 21, PA3003, https://doi.org/10.1029/2005PA001215, 2006.

Huguet, C., Urakawa, H., Martens-Habbena, W., Truxal, L., Stahl, D. A., and Ingalls, A. E.: Changes in intact membrane lipid content of archaeal cells as an indication of metabolic status, Org. Geochem., 41, 930-934, https://doi.org/10.1016/j.orggeochem.2010.04.012, 2010.

Huguet, C., Martrat, B., Grimalt, J. O., Sinninghe Damsté, J. S., and Schouten, S.: Coherent millennial-scale patterns in $\mathrm{U}_{37}^{k^{\prime}}$ and $\mathrm{TEX}_{86}^{H}$ temperature records during the penultimate interglacial-to-glacial cycle in the western
Mediterranean, Paleoceanogr. Paleoclimatol., 26, PA2218, https://doi.org/10.1029/2010PA002048, 2011.

Huguet, C., Fietz, S., and Rosell-Melé, A.: Global distribution patterns of hydroxy glycerol dialkyl glycerol tetraethers, Org. Geochem., 57, 107-118, https://doi.org/10.1016/j.orggeochem.2013.01.010, 2013.

Huguet, C., Fietz, S., Rosell-Mele, A., Daura, X., and Costenaro, L.: Molecular dynamics simulation study of the effect of glycerol dialkyl glycerol tetraether hydroxylation on membrane thermostability, BBA-Biomembranes, 1859, 966-974, https://doi.org/10.1016/j.bbamem.2017.02.009, 2017.

Hurley, S. J., Lipp, J. S., Close, H. G., Hinrichs, K. U., and Pearson, A.: Distribution and export of isoprenoid tetraether lipids in suspended particulate matter from the water column of the Western Atlantic Ocean, Org. Geochem., 116, 90-102, https://doi.org/10.1016/j.orggeochem.2017.11.010, 2018.

Ingalls, A. E., Shah, S. R., Hansman, R. L., Aluwihare, L. I., Santos, G. H., Druffel, E. R. M., and Pearson, A.: Quantifying archaeal community autotrophy in the mesopelagic ocean using natural radiocarbon, P. Natl. Acad. Sci. USA, 103, 6442-6447, https://doi.org/10.1073/pnas.0510157103, 2006.

Ingalls, A. E, Huguet, C., and Truxal, L.: Distribution of Intact and Core Membrane Lipids of Archaeal Glycerol Dialkyl Glycerol Tetraethers among Size-Fractionated Particulate Organic Matter in Hood Canal, Puget Sound, Appl. Environ. Microb., 78, 14801490, https://doi.org/10.1128/AEM.07016-11, 2012.

Jacobs, S. S., Hellmer, H. H., and Jenkins, A.: Antarctic ice sheet melting in the Southeast Pacific, Geophys. Res. Lett., 23, $957-$ 960, https://doi.org/10.1029/96g100723, 1996.

Jacobs, S. S., Jenkins, A., Giulivi, C. F., and Dutrieux, P.: Stronger ocean circulation and increased melting under Pine Island Glacier ice shelf, Nat. Geosci., 4, 519-523, https://doi.org/10.1038/ngeo1188, 2011.

Jenkins, A., Dutrieux, P., Jacobs, S. S., McPhail, S. D., Perrett, J. R., Webb, A. T., and White, D.: Observations beneath Pine Island Glacier in West Antarctica and implications for its retreat, Nat. Geosci., 3, 468-472, https://doi.org/10.1038/ngeo890, 2010.

Jenkyns, H. C., Forster, A., Schouten, S., and Sinninghe Damsté, J. S.: High temperatures in the Late Cretaceous Arctic Ocean, Nature, 432, 888-892, https://doi.org/10.1038/nature03143, 2004.

Joughin, I., Smith, B. E., and Medley, B.: Marine ice sheet collapse potentially under way for the Thwaites Glacier Basin, West Antarctica, Science, 344, 735-738, https://doi.org/10.1126/science.1249055, 2014.

Kalanetra, K. M., Bano, N., and Hollibaugh, J. T.: Ammoniaoxidizing archaea in the Arctic Ocean and Antarctic coastal waters, Environ. Microbiol., 11, 2434-2445, https://doi.org/10.1111/j.1462-2920.2009.01974.x, 2009.

Kang, S. J., Shin, K. H., and Kim, J. H.: Occurrence and distribution of hydroxylated isoprenoid glycerol dialkyl glycerol tetraethers (OH-GDGTs) in the Han River system, South Korea, Acta Geochim., 36, 367-369, https://doi.org/10.1007/s11631017-0165-3, 2017.

Kim, J.-G., Park, S.-J., Quan, Z.-X., Jung, M.-Y., Cha, I.-T., Kim, S.-J., Kim, K.-H., Yang, E.-J., Kim, Y.-N., Lee, S.-H., and Rhee, S.-K.: Unveiling abundance and distribution of planktonic bacteria and archaea in a polynya in Amundsen Sea, Antarctica, Environ. Microbiol., 16, 1566-1578, https://doi.org/10.1111/14622920.12287, 2014. 
Kim, J.-H., Schouten, S., Hopmans, E. C., Donner, B., and Sinninghe Damsté, J. S.: Global sediment core-top calibration of the TEX $_{86}$ paleothermometer in the ocean, Geochim. Cosmochim. Ac., 72, 1154-1173, 2008.

Kim, J.-H., van der Meer, J., Schouten, S., Helmke, P., Willmott, V., Sangiorgi, F., Koç, N., Hopmans, E. C., and Sinninghe Damsté, J. S.: New indices and calibrations derived from the distribution of crenarchaeal isoprenoid tetraether lipids: Implications for past sea surface temperature reconstructions, Geochim. Cosmochim. Ac., 74, 4639-4654, https://doi.org/10.1016/j.gca.2010.05.027, 2010.

Kim, J.-H., Crosta, X., Willmott, V., Renssen, H., Bonnin, J., Helmke, P., Schouten, S., and Sinninghe Damsté, J. S.: Holocene subsurface temperature variability in the eastern Antarctic continental margin, Geophys. Res. Lett., 39, L06705, https://doi.org/10.1029/2012g1051157, 2012.

Kim, J.-H., Villanueva, L., Zell, C., and Sinninghe Damsté, J. S.: Biological source and provenance of deep-water derived isoprenoid tetraether lipids along the Portuguese continental margin, Geochim. Cosmochim. Ac., 172, 177-204, https://doi.org/10.1016/j.gca.2015.09.010, 2016.

Kirchman, D. L., Elifantz, H., Dittel, A. I., Malmstrom, R. R., and Cottrell, M. T.: Standing stocks and activity of Archaea and Bacteria in the western Arctic Ocean, Limnol. Oceanogr., 52, 495507, https://doi.org/10.4319/lo.2007.52.2.0495, 2007.

Lee, S. H., Kang, Y.-C., and Fuhrman, J. A.: Imperfect retention of natural bacterioplankton cells by glass fiber filters, Mar. Ecol. Prog. Ser., 119, 285-290, https://doi.org/10.3354/meps119285, 1995.

Legendre, P. and Legendre, L.: Numerical Ecology, edn. 3, Elsevier, Oxford, UK, ISBN 978-0-444-53869-7, 2012.

Legendre, P., Oksanen, J., and ter Braak, C. J.: Testing the significance of canonical axes in redundancy analysis, Methods Ecol. Evol., 2, 269-277, https://doi.org/10.1111/j.2041210X.2010.00078.x, 2011.

Lengger, S. K., Hopmans, E. C., Sinninhe Damsté, J. S., and Schouten, S.: Comparison of extraction and work up techniques for analysis of core and intact polar tetraether lipids from sedimentary environments, Org. Geochem., 47, 34-40, https://doi.org/10.1016/j.orggeochem.2012.02.009, 2012.

Lengger, S. K., Kraaij, M., Tjallingii, R., Baas, M., Stuut, J.-B., Hopmans, E. C., Sinninghe Damsté, J. S., and Schouten, S.: Differential degradation of intact polar and core glycerol dialkyl glycerol tetraether lipids upon post-depositional oxidation, Org. Geochem., 65, 83-93, https://doi.org/10.1016/j.orggeochem.2013.10.004, 2013.

Lengger, S. K., Hopmans, E. C., Sinninghe Damsté, J. S., and Schouten, S.: Fossilization and degradation of archaeal intact polar tetraether lipids in deeply buried marine sediments (Peru Margin), Geobiology, 12, 212-220, https://doi.org/10.1111/gbi.12081, 2014.

Lincoln, S. A., Wai, B., Eppley, J. M., Church, M. J., Summons, R. E., and DeLong, E. F.: Planktonic Euryarchaeota are a significant source of archaeal tetraether lipids in the ocean, P. Natl. Acad. Sci. USA, 111, 9858-9863, https://doi.org/10.1073/pnas.1409439111, 2014a.

Lincoln, S. A., Wai, B., Eppley, J. M., Church, M. J., Summons, R. E., and DeLong, E. F.: Reply to Schouten et al.: Marine Group II planktonic Euryarchaeota are significant contributors to tetraether lipids in the ocean, P. Natl. Acad. Sci. USA, 111, E4286, https://doi.org/10.1073/pnas.1416736111, 2014b.

Lipp, J. S. and Hinrichs, K. U.: Structural diversity and fate of intact polar lipids in marine sediments, Geochim. Cosmochim. Ac., 73, 6816-6833, https://doi.org/10.1016/j.gca.2009.08.003, 2009.

Lipp, J. S., Morono, Y., Inagaki, F., and Hinrichs, K. U.: Significant contribution of Archaea to extant biomass in marine subsurface sediments, Nature, 454, 991-994, https://doi.org/10.1038/nature07174, 2008.

Liu, X. L., Lipp, J. S., Simpson, J. H., Lin, Y. S., Summons, R. E., and Hinrichs, K. U.: Mono- and dihydroxyl glycerol dibiphytanyl glycerol tetraethers in marine sediments: Identification of both core and intact polar lipid forms, Geochim. Cosmochim. Ac., 89, 102-115, https://doi.org/10.1016/j.gca.2012.04.053, 2012.

Locarnini, R. A., Whitworth, T., and Nowlin, W. D.: The importance of the Scotia Sea on the outflow of Weddell Sea Deep Water, J. Mar. Res., 51, 135-153, https://doi.org/10.1357/0022240933223846, 1993.

Lu, X. X., Liu, X. L., Elling, F. J., Yang, H., Xie, S. C., Song, J. M., Li, X. G., Yuan, H. M., Li, N., and Hinrichs, K. U.: Hydroxylated isoprenoid GDGTs in Chinese coastal seas and their potential as a paleotemperature proxy for midto-low latitude marginal seas, Org. Geochem., 89-90, 31-43, https://doi.org/10.1016/j.orggeochem.2015.10.004, 2015.

Luo, H. W., Tolar, B. B., Swan, B. K., Zhang, C. L. L., Stepanauskas, R., Moran, M. A., and Hollibaugh, J. T.: Single-cell genomics shedding light on marine Thaumarchaeota diversification, Isme J., 8, 732-736, https://doi.org/10.1038/ismej.2013.202, 2014.

Mankoff, K. D., Jacobs, S. S., Tulaczyk, S. M., and Stammerjohn, S. E.: The role of Pine Island Glacier ice shelf basal channels in deep-water upwelling, polynyas and ocean circulation in Pine Island Bay, Antarctica, Ann. Glaciol., 53, 123-128, https://doi.org/10.3189/2012AoG60A062, 2012.

Massana, R., Taylor, L. J., Murray, A. E., Wu, K. Y., Jeffrey, W. H., and DeLong, E. F.: Vertical distribution and temporal variation of marine planktonic archaea in the Gerlache Strait, Antarctica, during early spring, Limnol. Oceanogr., 43, 607-617, https://doi.org/10.4319/lo.1998.43.4.0607, 1998.

Menviel, L., Timmermann, A., Timm, O. E., and Mouchet, A.: Climate and biogeochemical response to a rapid melting of the West Antarctic Ice Sheet during interglacials and implications for future climate, Paleoceanography, 25, PA4231, https://doi.org/10.1029/2009PA001892, 2010.

Merbt, S. N., Stahl, D. A., Casamayor, E. O., Marti, E., Nicol, G. W., and Prosser, J. I.: Differential photoinhibition of bacterial and archaeal ammonia oxidation, Fems Microbiol. Lett., 327, 41-46, https://doi.org/10.1111/j.1574-6968.2011.02457.x, 2012.

Meredith, M. P., Naveira Garabato, A. C., Stevens, D. P., Heywood, K. J., and Sanders, R. J.: Deep and Bottom Waters in the Eastern Scotia Sea: Rapid Changes in Properties and Circulation, J. Phys. Oceanogr., 31, 2157-2168, https://doi.org/10.1175/15200485(2001)031<2157:DABWIT>2.0.CO;2, 2001.

Mincer, T. J., Church, M. J., Taylor, L. T., Preston, C., Kar, D. M., and DeLong, E. F.: Quantitative distribution of presumptive archaeal and bacterial nitrifiers in Monterey Bay and the North Pacific Subtropical Gyre, Environ. Microbiol., 9, 11621175, https://doi.org/10.1111/j.1462-2920.2007.01239.x, 2007. 
Mouginot, J., Rignot, E., and Scheuchl, B.: Sustained increase in ice discharge from the Amundsen Sea Embayment, West Antarctica, from 1973 to 2013, Geophys. Res. Lett., 41, 1576-1584, https://doi.org/10.1002/2013GL059069, 2014.

Murray, A. E., Preston, C. M., Massana, R., Taylor, L. T., Blakis, A., Wu, K., and DeLong, E. F.: Seasonal and spatial variability of bacterial and archaeal assemblages in the coastal waters near Anvers Island, Antarctica, Appl. Environ. Microb., 64, 2585-2595, 1998.

Naveira Garabato, A. C., Heywood, K. J., and Stevens, D. P.: Modification and pathways of Southern Ocean Deep Waters in the Scotia Sea, Deep-Sea Res. Pt. I, 49, 681-705, https://doi.org/10.1016/S0967-0637(01)00071-1, 2002a.

Naveira Garabato, A. C., Strass, V. H., and Kattner, G.: Fluxes of nutrients in a three-dimensional meander structure of the Antarctic Polar Front, Deep-Sea Res. Pt. II, 49, 3771-3792, https://doi.org/10.1016/S0967-0645(02)00110-8, 2002b.

Oksanen, J., Blanchet, F. G., Friendly, M., Kindt, R., Legendre, P., McGlinn, D., Minchin, P. R., O'Hara, R. B., Simpson, G. L., Solymos, P., Stevens, M. H. H., Szoecs, E., and Wagner, H.: vegan: Community Ecology Package, R-Package Version 2.56, available at: https://CRAN.R-project.org/package=vegan (last access: 22 March 2021), 2019.

Orsi, A. H., Whitworth, T., and Nowlin Jr., W. D.: On the meridional extent and fronts of the Antarctic Circumpolar Current, Deep-Sea Res. Pt. I, 42, 641-673, https://doi.org/10.1016/09670637(95)00021-W, 1995.

Paolo, F. S., Fricker, H. A., and Padman, L.: Volume loss from Antarctic ice shelves is accelerating, Science, 348, 327-331, https://doi.org/10.1126/science.aaa0940, 2015.

Park, J., Kuzminov, F. I., Bailleul, B., Yang, E. J., Lee, S., Falkowski, P. G., and Gorbunov, M. Y.: Light availability rather than Fe controls the magnitude of massive phytoplankton bloom in the Amundsen Sea polynyas, Antarctica, Limnol. Oceanogr., 62, 2260-2276, https://doi.org/10.1002/lno.10565, 2017.

Pitcher, A., Hopmans, E. C., Schouten, S., and Sinninghe Damsté, J. S.: Separation of core and intact polar archaeal tetraether lipids using silica columns: Insights into living and fossil biomass contributions, Org. Geochem., 40, 12-19, https://doi.org/10.1016/j.orggeochem.2008.09.008, 2009.

Pitcher, A., Rychlik, N., Hopmans, E. C., Spieck, E., Rijpstra, W. I. C., Ossebaar, J., Schouten, S., Wagner, M., and Sinninghe Damsté, J. S.: Crenarchaeol dominates the membrane lipids of "Candidatus Nitrososphaera gargensis", a thermophilic Group I.1b Archaeon, Isme J., 4, 542-552, https://doi.org/10.1038/ismej.2009.138, 2010.

Pitcher, A., Hopmans, E. C., Mosier, A. C., Park, S. J., Rhee, S. K., Francis, C. A., Schouten, S., and Sinninghe Damsté, J. S.: Core and Intact Polar Glycerol Dibiphytanyl Glycerol Tetraether Lipids of Ammonia-Oxidizing Archaea Enriched from Marine and Estuarine Sediments, Appl. Environ. Microb., 77, 34683477, https://doi.org/10.1128/Aem.02758-10, 2011.

Pritchard, H. D., Arthern, R. J., Vaughan, D. G., and Edwards, L. A.: Extensive dynamic thinning on the margins of the Greenland and Antarctic ice sheets, Nature, 461, 971-975, https://doi.org/10.1038/nature08471, 2009.

Raes, E. J., Bodrossy, L., van de Kamp, J., Bissett, A., Ostrowski, M., Brown, M. V., Sow, S. L. S., Sloyan, B., and Waite, A. M.: Oceanographic boundaries constrain microbial diversity gradi- ents in the South Pacific Ocean, P. Natl. Acad. Sci. USA, 115, 8266-8275, https://doi.org/10.1073/pnas.1719335115, 2018.

Raiswell, R., Benning, L. G., Tranter, M., and Tulaczyk, S.: Bioavailable iron in the Southern Ocean: the significance of the iceberg conveyor belt, Geochem. T., 9, 7, https://doi.org/10.1186/1467-4866-9-7, 2008.

Rignot, E. and Jacobs, S. S.: Rapid bottom melting widespread near Antarctic ice sheet grounding lines, Science, 296, 2020-2023, https://doi.org/10.1126/science.1070942, 2002.

Rignot, E., Bamber, J. L., Van Den Broeke, M. R., Davis, C., Li, Y. H., Van De Berg, W. J., and Van Meijgaard, E.: Recent Antarctic ice mass loss from radar interferometry and regional climate modelling, Nat. Geosci., 1, 106-110, https://doi.org/10.1038/ngeo102, 2008.

Rignot, E., Jacobs, S., Mouginot, J., and Scheuchl, B.: IceShelf Melting Around Antarctica, Science, 341, 266-270, https://doi.org/10.1126/science.1235798, 2013.

Rignot, E., Mouginot, J., Scheuchl, B., Van Den Broeke, M., Van Wessem, M. J., and Morlighem, M.: Four decades of Antarctic ice sheet mass balance from 1979-2017, P. Natl. Acad. Sci. USA, 116, 1095-1103, https://doi.org/10.1073/pnas.1812883116, 2019.

Rubin, S. I.: Carbon and nutrient cycling in the upper water column across the Polar Frontal Zone and Antarctic Circumpolar Current along $170^{\circ} \mathrm{W}$, Global Biogeochem. Cy., 17, 1087, https://doi.org/10.1029/2002GB001900, 2003.

Schouten, S., Hopmans, E. C., Pancost, R. D., and Sinninghe Damsté, J. S.: Widespread occurrence of structurally diverse tetraether membrane lipids: Evidence for the ubiquitous presence of low-temperature relatives of hyperthermophiles, P. Natl. Acad. Sci. USA, 97, 14421-14426, https://doi.org/10.1073/pnas.97.26.14421, 2000.

Schouten, S., Hopmans, E. C., Schefuß, E., and Sinninghe Damsté, J. S.: Distributional variations in marine crenarchaeotal membrane lipids: a new tool for reconstructing ancient sea water temperatures?, Earth Planet. Sc. Lett., 204, 265-274, https://doi.org/10.1016/S0012-821X(02)00979-2, 2002.

Schouten, S., Huguet, C., Hopmans, E. C., Kienhuis, M. V. M., and Sinninghe Damsté, J. S.: Analytical methodology for $\mathrm{TEX}_{86}$ paleothermometry by high-performance liquid chromatography/atmospheric pressure chemical ionization-mass spectrometry, Anal. Chem., 79, 2940-2944, https://doi.org/10.1021/ac062339v, 2007.

Schouten, S., Baas, M., Hopmans, E. C., Reysenbach, A. L., and Sinninghe Damsté, J. S.: Tetraether membrane lipids of Candidatus "Aciduliprofundum boonei", a cultivated obligate thermoacidophilic euryarchaeote from deep-sea hydrothermal vents, Extremophiles, 12, 119-124, https://doi.org/10.1007/s00792-0070111-0, 2008.

Schouten, S., Middelburg, J. J., Hopmans, E. C., and Sinninghe Damsté, J. S.: Fossilization and degradation of intact polar lipids in deep subsurface sediments: A theoretical approach, Geochim. Cosmochim. Ac., 74, 3806-3814, https://doi.org/10.1016/j.gca.2010.03.029, 2010.

Schouten, S., Pitcher, A., Hopmans, E. C., Villanueva, L., van Bleijswijk, J., and Sinninghe Damsté, J. S.: Intact polar and core glycerol dibiphytanyl glycerol tetraether lipids in the Arabian Sea oxygen minimum zone: I. Selective preservation and degradation in the water column and consequences 
for the $\mathrm{TEX}_{86}$, Geochim. Cosmochim. Ac., 98, 228-243, https://doi.org/10.1016/j.gca.2012.05.002, 2012.

Schouten, S., Hopmans, E. C., and Sinninghe Damsté, J. S.: The organic geochemistry of glycerol dialkyl glycerol tetraether lipids: A review, Org. Geochem., 54, 19-61, https://doi.org/10.1016/j.orggeochem.2012.09.006, 2013a.

Schouten, S., Hopmans, E. C., Rosell-Melé, A., Pearson, A., Adam, P., Bauersachs, T., Bard, E., Bernasconi, S. M., Bianchi, T. S., Brocks, J. J., Carlson, L. T., Castañeda, I. S., Derenne, S., Selver, A. D., Dutta, K., Eglinton, T., Fosse, C., Galy, V., Grice, K., Hinrichs, K. U., Huang, Y., Huguet, A., Huguet, C., Hurley, S., Ingalls, A., Jia, G., Keely, B., Knappy, C., Kondo, M., Krishnan, S., Lincoln, S., Lipp, J., Mangelsdorf, K., Martínez-García, A., Ménot, G., Mets, A., Mollenhauer, G., Ohkouchi, N., Ossebaar, J., Pagani, M., Pancost, R. D., Pearson, E. J., Peterse, F., Reichart, G. J., Schaeffer, P., Schmitt, G., Schwark, L., Shah, S. R., Smith, R. W., Smittenberg, R. H., Summons, R. E., Takano, Y., Talbot, H. M., Taylor, K. W. R., Tarozo, R., Uchida, M., Van Dongen, B. E., Van Mooy, B. A. S., Wang, J., Warren, C., Weijers, J. W. H., Werne, J. P., Woltering, M., Xie, S., Yamamoto, M., Yang, H., Zhang, C. L., Zhang, Y., Zhao, M., and Sinninghe Damsté, J. S.: An interlaboratory study of $\mathrm{TEX}_{86}$ and BIT analysis of sediments, extracts, and standard mixtures, Geochem. Geophy. Geosy., 14, 5263-5265, https://doi.org/10.1002/2013GC004904, 2013 b.

Schouten, S., Villanueva, L., Hopmans, E. C., van der Meer, M. T. J., and Sinninghe Damsté, J. S.: Are Marine Group II Euryarchaeota significant contributors to tetraether lipids in the ocean?, P. Natl. Acad. Sci. USA, 111, 4285, https://doi.org/10.1073/pnas.1416176111, 2014.

Schubotz, F., Wakeham, S. G., Lipp, J. S., Fredricks, H. F., and Hinrichs, K. U.: Detection of microbial biomass by intact polar membrane lipid analysis in the water column and surface sediments of the Black Sea, Environ. Microbiol., 11, 2720-2734, https://doi.org/10.1111/j.1462-2920.2009.01999.x, 2009.

Shah, S. R., Mollenhauer, G., Ohkouchi, N., Eglinton, T. I., and Pearson, A.: Origins of archaeal tetrarther lipids in sediments: Insights from radiocarbon analysis, Geochim. Cosmochim. Ac., 72, 4577-4594, https://doi.org/10.1016/j.gca.2008.06.021, 2008.

Shepherd, A., Wingham, D. J., Mansley, J. A. D., and Corr, H. F. J.: Inland thinning of Pine Island Glacier, West Antarctica, Science, 291, 862-864, https://doi.org/10.1126/science.291.5505.862, 2001.

Shevenell, A. E., Ingalls, A. E., Dormack, E. W., and Kelly, C.: Holocene Southern Ocean surface temperature variability west of the Antarctic Peninsula, Nature, 470, 250-254, https://doi.org/10.1038/nature09751, 2011.

Signori, C. N., Pellizari, V. H., Enrich-Prast, A., and Sievert, S. M.: Spatiotemporal dynamics of marine bacterial and archaeal communities in surface waters off the northern Antarctic Peninsula, Deep-Sea Res. Pt. II, 149, 150-160, https://doi.org/10.1016/j.dsr2.2017.12.017, 2018.

Sinninghe Damsté, J. S., van Bentum, E. C., Reichart, G.-J., Pross, J., and Schouten, S.: $\mathrm{A} \mathrm{CO}_{2}$ decrease-driven cooling and increased latitudinal temperature gradient during the midCretaceous Oceanic Anoxic Event 2, Earth Planet. Sc. Lett., 293, 97-103, https://doi.org/10.1016/j.eps1.2010.02.027, 2010.

Sinninghe Damsté, J. S., Rijpstra, W. I. C., Hopmans, E. C., Jung, M. Y., Kim, J. G., Rhee, S. K., Stieglmeier, M., and
Schleper, C.: Intact polar and core Glycerol Dibiphytanyl Glycerol Tetraether lipids of Group I. 1a and I. 1b Thaumarchaeota in soil, Appl. Environ. Microb., 78, 6866-6874, https://doi.org/10.1128/aem.01681-12, 2012.

Sinninghe Damsté, J. S., Rijpstra, W. I. C., Hopmans, E. C., den Uijl, M. J., Weijers, J. W. H., and Schouten, S.: The enigmatic structure of the crenarchaeol isomer, Org. Geochem., 124, 22-28, https://doi.org/10.1016/j.orggeochem.2018.06.005, 2018.

Smith, J. A., Andersen, T. J., Shortt, M., Truffer, M., Stanton, T. P., Bindschadler, R., Dutrieux, P., Jenkins, A., Hillenbrand, C.-D., Ehrmann, W., Corr, H. F. J., Farley, N., Crowhurst, S., and Vaughan, D. G.: Sub-ice-shelf sediments record history of 20th Century retreat of Pine Island Glacier, Nature, 540, 77-80, https://doi.org/10.1038/nature20136, 2017.

Sokolov, S. and Rintoul, S. R.: Circulation structure and distribution of the Antarctic Circumpolar Current fronts: 1. Mean circumpolar paths, J. Geophys. Res.-Oceans, 114, C11018, https://doi.org/10.1029/2008JC005248, 2009.

Sollai, M., Villanueva, L., Hopmans, E. C., Reichart, G.-J., and Sinninghe Damsté, J. S.: A combined lipidomic and 16S rRNA gene amplicon sequencing approach reveals archaeal sources of intact polar lipids in the stratified Black Sea water column, Geobiology, 17, 91-109, https://doi.org/10.1111/gbi.12316, 2019a.

Sollai, M., Villanueva, L., Hopmans, E. C., Keil, R. G., and Sinninghe Damsté, J. S.: Archaeal sources of intact membrane lipid biomarkers in the oxygen deficient zone of the Eastern Tropical South Pacific, Front. Microbiol., 10, 765, https://doi.org/10.3389/fmicb.2019.00765, 2019b.

Sollich, M., Yoshinaga, M. Y., Hausler, S., Price, R. E., Hinrichs, K. U., and Buhring, S. I.: Heat stress dictates microbial lipid composition along a thermal gradient in marine sediments, Front. Microbiol., 8, 1550, https://doi.org/10.3389/fmicb.2017.01550, 2017.

Spang, A., Hatzenpichler, R., Brochier-Armanet, C., Rattei, T., Tischler, P., Spieck, E., Streit, W., Stahl, D. A., Wagner, M., and Schleper, C.: Distinct gene set in two different lineages of ammonia-oxidizing archaea supports the phylum Thaumarchaeota, Trends Microbiol., 18, 331-340, https://doi.org/10.1016/j.tim.2010.06.003, 2010.

St-Laurent, P., Yager, P. L., Sherrell, R. M., Stammerjohn, S. E., and Dinniman, M. S.: Pathways and supply of dissolved iron in the Amundsen Sea (Antarctica), J. Geophys. Res.-Oceans, 122, 7135-7162, https://doi.org/10.1002/2017JC013162, 2017.

Sturt, H. F., Summons, R. E., Smith, K., Elvert, M., and Hinrichs, K. U.: Intact polar membrane lipids in prokaryotes and sediments deciphered by high-performance liquid chromatography/electrospray ionization multistage mass spectrometry - new biomarkers for biogeochemistry and microbial ecology, Rapid Commun. Mass Sp., 18, 617-628, https://doi.org/10.1002/rcm.1378, 2004.

Thuroczy, C.-E., Alderkamp, A.-C., Laan, P., Gerringa, L. J. A., Mills, M. M., Van Dijken, G. L., De Baar, H. J. W., and Arrigo, K. R.: Key role of organic complexation of iron in sustaining phytoplankton blooms in the Pine Island and Amundsen Polynyas (Southern Ocean), Deep-Sea Res. Pt. II, 71-76, 49-60, https://doi.org/10.1016/j.dsr2.2012.03.009, 2012.

Tolar, B. B., Ross, M. J., Wallsgrove, N. J., Liu, Q., Aluwihare, L. I., Popp, B. N., and Hollibaugh, J. T.: Contribution of ammonia 
oxidation to chemoautotrophy in Antarctic coastal waters, Isme J., 10, 2605-2619, https://doi.org/10.1038/ismej.2016.61, 2016.

Venables, H. J.: JR272A Weddell and Scotia Sea hydrographic section, British Antarctic Survey, Cambridge, UK, https://www.bodc.ac.uk/resources/inventories/cruise_inventory/ reports/jr272.pdf (last access: 22 March 2021), 2012.

Vernet, M., Geibert, W., Hoppema, M., Brown, P. J., Haas, C., Hellmer, H. H., Jokat, W., Jullion, L., Mazloff, M., Bakker, D. C. E., Brearley, J. A., Croot, P., Hattermann, T., Hauck, J., Hillenbrand, C.-D., Hoppe, C. J. M., Huhn, O., Koch, B. P., Lechtenfeld, O. J., Meredith, M. P., Naveira Garabato, A. C., Nöthig, E.-M., Peeken, I., Rutgers van der Loeff, M. M., Schmidtko, S., Schröder, M., Strass, V. H., Torres-Valdés, S., and Verdy, A.: The Weddell Gyre, Southern Ocean: Present knowledge and future challenges, Rev. Geophys., 57, 623-708, https://doi.org/10.1029/2018RG000604, 2019.

Wadham, J. L., De'ath, R., Monteiro, F. M., Tranter, M., Ridgwell, A., Raiswell, R., and Tulaczyk, S.: The potential role of the Antarctic Ice Sheet in global biogeochemical cycles, Earth Env. Sci. T. R. So., 104, 55-67, https://doi.org/10.1017/S1755691013000108, 2013.

Wadham, J. L., Hawkings, J. R., Tarasov, L., Gregoire, L. J., Spencer, R. G. M., Gutjahr, M., Ridgwell, A., and Kohfeld, K. E.: Ice sheets matter for the global carbon cycle, Nat. Commun., 10, 3567, https://doi.org/10.1038/s41467-019-11394-4, 2019.

Webber, B. G. M., Heywood, K. J., Stevens, D. P., Dutrieux, P., Abrahamsen, E. P., Jenkins, A., Jacobs, S. S., Ha, H. K., Lee, S. H., and Kim, T. W.: Mechanisms driving variability in the ocean forcing of Pine Island Glacier, Nat. Commun., 8, 14507, https://doi.org/10.1038/ncomms14507, 2017.

Weber, Y., Sinninghe Damsté, J. S., Hopmans, E. C., Lehmann, M. F., and Niemann, H.: Incomplete recovery of intact polar glycerol dialkyl glycerol tetraethers from lacustrine suspended biomass, Limnol. Oceanogr.-Meth., 15, 782-793, https://doi.org/10.1002/lom3.10198, 2017.

Wilkins, D., Lauro, F. M., Williams, T. J., Demaere, M. Z., Brown, M. V., Hoffman, J. M., Andrews-Pfannkoch, C., Mcquaid, J. B., Riddle, M. J., Rintoul, S. R., and Cavicchioli, R.: Biogeographic partitioning of Southern Ocean microorganisms revealed by metagenomics, Environ. Microbiol., 15, 1318-1333, https://doi.org/10.1111/1462-2920.12035, 2013.
Wingham, D. J., Wallis, D. W., and Shepherd, A.: Spatial and temporal evolution of Pine Island Glacier thinning, 1995-2006, Geophys. Res. Lett., 36, L17501, https://doi.org/10.1029/2009g1039126, 2009.

Xie, S. T., Lipp, J. S., Wegener, G., Ferdelman, T. G., and Hinrichs, K.-U.: Turnover of microbial lipid in the deep biosphere and growth of benthic archaeal populations, P. Natl. Acad. Sci. USA, 100, 6010-6014, https://doi.org/10.1073/pnas.1218569110, 2013.

Xie, S. T., Liu, X. L., Schubotz, F., Wakeham, S. G., and Hinrichs, K.-U.: Distribution of glycerol ether lipids in the oxygen minimum zone of the Eastern Tropical North Pacific Ocean, Org. Geochem., 71, 60-71, https://doi.org/10.1016/j.orggeochem.2014.04.006, 2014.

Yager, P. L., Sherrell, R. M., Stammerjohn, S. E., Alderkamp, A.C., Schofield, O., Abrahamsen, E. P., Arrigo, K. R., Bertilsson, S., Garay, D. L., Guerrero, R., Lowry, K. E., Moksnes, P.-O., Ndungu, K., Post, A. F., Randall-Goodwin, E., Riemann, L., Severmann, S., Thatje, S., van Dijken, G. L., and Wilson, S.: ASPIRE: The Amundsen sea Polynya international research expedition, Oceanography, 25, 40-53, https://doi.org/10.5670/oceanog.2012.73, 2012.

Zeng, Z., Liu, X.-L., Farley, K. R., Wei, J. H., Metcalf, W. W., Summons, R. E., and Welander, P. V.: GDGT cyclization proteins identify the dominant archaeal sources of tetraether lipids in the ocean, P. Natl. Acad. Sci. USA, 45, 22505-22511, https://doi.org/10.1073/pnas.1909306116, 2019.

Zhang, Y. G., Pagani, M., and Zhengrong, W.: Ring Index: A new strategy to evaluate the integrity of $\mathrm{TEX}_{86}$ paleothermometry, Paleoceanography, 31, 220-232, https://doi.org/10.1002/2015PA002848, 2016.

Zhu, C., Wakeham, S. G., Elling, F. J., Basse, A., Mollenhauer, G., Versteegh, G. J. M., Konneke, M., and Hinrichs, K.-U.: Stratification of archaeal membrane lipids in the ocean and implications for adaptation and chemotaxonomy of planktonic archaea, Environ. Microbiol., 18, 4324-4336, https://doi.org/10.1111/14622920.13289, 2016.

Zwally, H. J., Giovinetto, M. B., Li, J., Cornejo, H. G., Beckley, M. A., Brenner, A. C., Saba, J. L., and Yi, D. H.: Mass changes of the Greenland and Antarctic ice sheets and shelves and contributions to sea-level rise: 1992-2002, J. Glaciol., 51, 509-527, https://doi.org/10.3189/172756505781829007, 2005. 